\title{
Agricultural and Other Biotechnological Applications Resulting from Trophic Plant-Endophyte Interactions
}

\author{
Agnieszka Kuźniar®D, Kinga Włodarczyk and Agnieszka Wolińska * \\ Department of Biology and Biotechnology of Microorganisms, The John Paul II Catholic University of Lublin, \\ Konstantynów St. 1 I, 20-708 Lublin, Poland; agnieszka.kuzniar@kul.pl (A.K.); kingawlodarczyk@kul.pl (K.W.) \\ * Correspondence: awolin@kul.pl; Tel.: +48-814-545-460
}

Received: 5 November 2019; Accepted: 18 November 2019; Published: 20 November 2019

\begin{abstract}
Endophytic microbiota plays a role not only in supplying plants with the basic nutrients indispensable for their growth, but also helps them in the mechanisms of adaptation to various environmental stresses (i.e., salinity, drought), which is important in the aspect of crop yields. From the agricultural and biotechnological points of view, the knowledge of endophytes and their roles in increasing crop yields, plant resistance to diseases, and helping to survive environmental stress is extremely desirable. This paper reviews some of the beneficial plant-microbe interactions that might be potentially used in both agriculture (plant growth stimulation effect, adaptation of host organisms in salinity and drought conditions, and support of defense mechanisms in plants), and in biotechnology (bioactive metabolites, application of endophytes for bioremediation and biotransformation processes, and production of biofertilizers and biopreparations). Importantly, relatively recent reports on endophytes from the last 10 years are summarized in this paper.
\end{abstract}

Keywords: endophytic microbiota; plant growth stimulation; biopreparates; metabolites; biotechnology; agriculture

\section{Introduction}

Interactions between living organisms usually result in increased biodiversity [1,2]. A common phenomenon in nature is the interactions between species from different domains: Archaea, Bacteria, and Eukarya.

Endophytes are commonly defined as microbiota (bacteria, fungi), spending at least part of their lives inside plants [2-4]. De Bary first introduced this term in 1866, but Darnelin initiated the first study on the biology of endophytes of a field weed (Agrostemma githago L.) in 1904 [5]. Biota that can be isolated from surface-disinfested plant tissue and/or extracted from within the plant is regarded as endophytes [4]. It is worth mentioning that this definition was valid for over the past two decades, but only in relation to cultivable species [4]. However, with the development of cultivation-independent methods, a more precise and accurate definition of endophytes seemed to be desirable. Hardoim et al. [4] postulated that the "endophyte" term should refer to the habitat only, not the function, and, therefore, this definition should be more general and include all microorganisms that colonize internal plant tissues throughout, or part, of their lifetime.

Endophytic microbiota generally colonizes intercellular spaces, but some can enter cells [6]. These organisms are isolated from stems, roots, leaves, fruits, bulbs, and seeds [7]. Some of them stimulate the growth of plants [8], provide protection against biotic and abiotic stress [7,9], facilitate nutrient absorption from soil [10], and contribute to nitrogen assimilation [11]. All of these features are extremely important from the agricultural and biotechnological points of view.

Several potential applications of endophytes can be found in the literature (Figure 1), which mainly include [3,12-14]: 
(a) biosynthesis of factors stimulating plant growth and endophytic strains applied for commercial-scale production as bio-fertilizers and bio-preparations,

(b) plant protection against pathogens and diseases,

(c) improvement of ecological adaptation of the host, and

(d) biotransformation of bioactive compounds and bioactive metabolites.

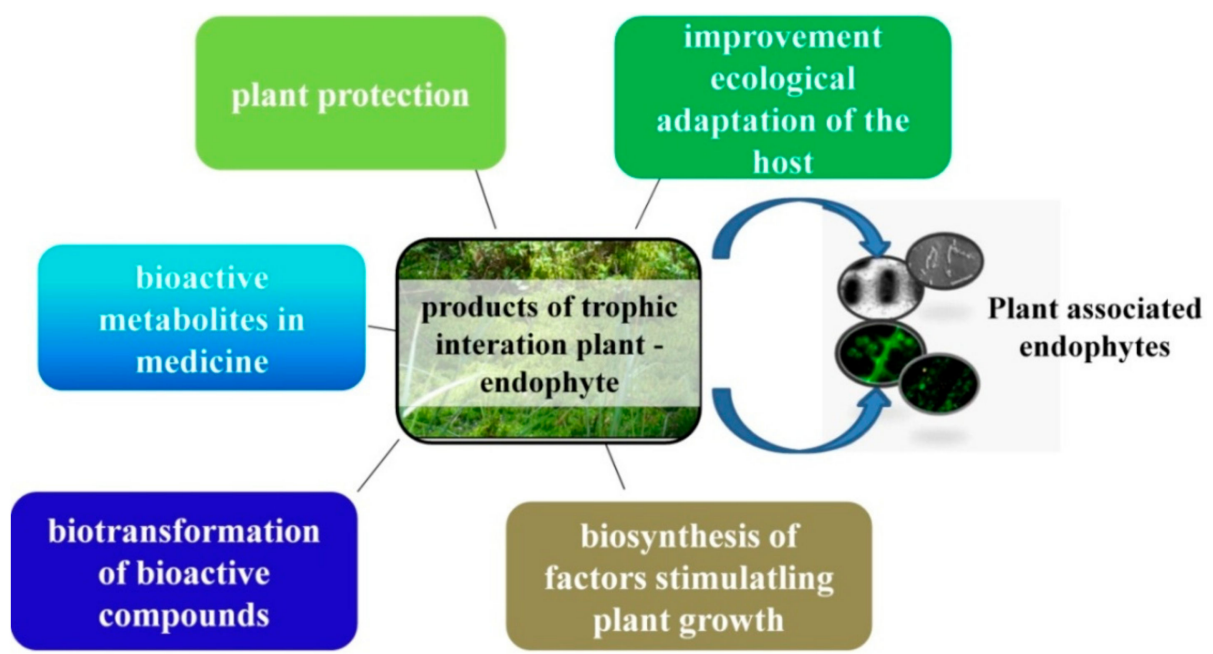

Figure 1. Usefulness of products resulting from trophic-plant interactions of endophytes in agriculture and biotechnology. Oval images present plant associated endophytes seen under the fluorescence and electron microscopes (photos taken by the authors).

\section{Next Generation Sequencing Platforms as an Effective Tool in Identification of Endophytes}

The Next-Generation Sequencing (NGS) technology is one of the most important techniques for microbiological research [13,15-18]. It has contributed to the emergence of metagenomics, i.e., an analysis of the genome of microorganisms by only DNA extraction without the necessity of cultivating microorganisms on artificial media [16,18,19]. Dijk et al. [20] and Wolińska et al. [21] suggested that the NGS technique contributed to overcoming the shortages and limitations that are connected with detection of only the most abundant and cultivated genera.

The sequencing proceeds through a cycle of washing and flooding fragments with known nucleotides in sequential order. As nucleotides incorporate into the growing DNA strand, they are digitally recorded as a sequence [22-24]. Three basic platforms can be distinguished in NGS: Roche 454-pyrosequencing, Ion Torrent, and Illumina sequencing. They differ in the average length of the base pair reading (Roche $454-500$ base pairs, Ion Torrent 200-300 base pairs, Illumina 120-150 for SR200, and 250-300 base pairs for v2 250PE and v3 $300 \mathrm{PE}$, respectively) $[16,18,25]$. The Ion Torrent and the Illumina rely on a slightly different mechanism of detection of nucleotide sequences. The Personal Genome Machine (PGM) performs semiconductor sequencing that relies on the detection of $\mathrm{pH}$ changes that are induced by the release of a hydrogen ion upon the incorporation of a nucleotide into a growing strand of DNA $[26,27]$.

Recently, third-generation sequencing (TGS) techniques, known as long-read sequencing, become increasingly popular. TGS works by reading the nucleotide sequences at the single molecule level, making it well-suited for unsolved problems in genome, transcriptome, and epigenetic research, and it is represented by Pacific BioSciences, Menlo Park, CA, USA (PacBio) sequencing platform [28]. However, despite the fact that PacBio sequencing offers much longer read lengths and faster runs than typical NGS methods, it should be realized that it is hindered by a lower throughput, higher error rate, and higher cost per base [28]. The original PacBio RS system generated mean read lengths around 1500 bp [29], the PacBio RS II system boasts average read lengths over $10 \mathrm{~kb}$, with an N50 generated reads between 20 and $60 \mathrm{~kb}[28,29]$. 
It is worth emphasizing that the NGS technologies have significantly changed in recent years and their efficiency and quality have been improved [19]. NGS allows for sequencing millions of bases in one cycle. They are much cheaper in comparison with traditional methods of sequencing [22]. Thus, NGS is efficiently applied in molecular biology [30], phylogenetic and ecological studies, transcriptome research, and development of hybridization [22]. NGS helps to discover new plant viruses [31] and elucidate the diversity and function of microorganisms in the environment at a substantially lower cost [11]. NGS has increased the possibility of obtaining genomic sequences, which provides a better understanding of the genetic, genomic, developmental, and evolutionary processes that affect the diversity of plants on the Earth [22].

NGS facilitates studies of endophytic microbiomes, reveals bacterial biodiversity, and gives the possibility of in-depth analysis of bacterial communities in taxonomic and phylogenetic terms $[18,19,32]$. It is applied as an effective tool for the identification and characterization of endophytic bacteria, providing an understanding of their interactions with host plants $[12,15,17,23]$.

A list of the most recent metagenomic studies [11-17,23,24,32-40] has been prepared to summarize endophyte strains that can be potentially employed for specific plants and properties that have been enhanced (Table 1). It was demonstrated that plant growth promoting (PGP) abilities and biological nitrogen fixation, followed by the production of secondary metabolites and bioactive compounds, synthesis of fungicides and bactericides, and protection against environmental stresses are the most important benefits that are provided to plants by endophytes (Table 1).

Table 1. Beneficial functions of metagenomically identified endophytes colonizing different parts of plants.

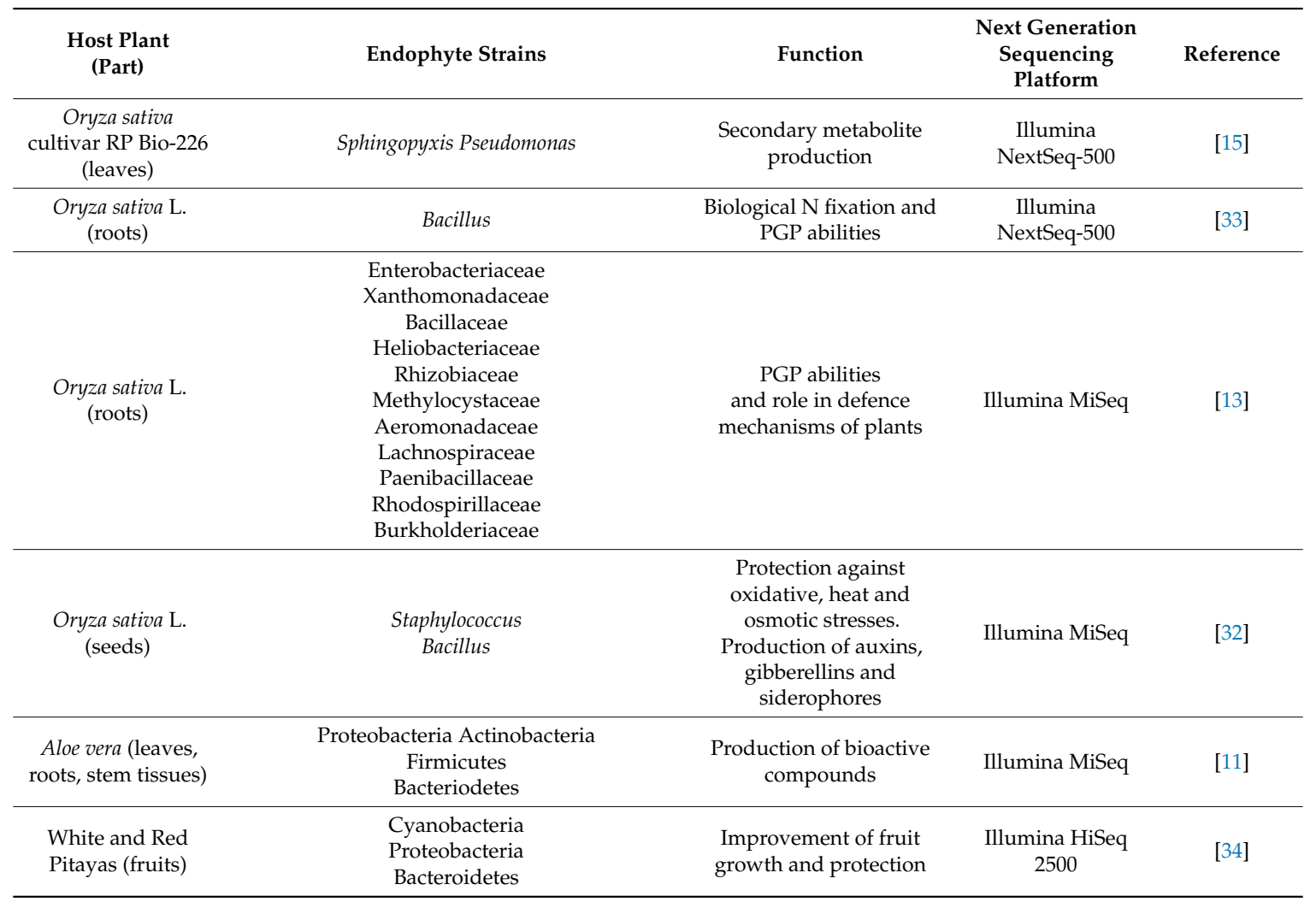


Table 1. Cont.

\begin{tabular}{|c|c|c|c|c|}
\hline $\begin{array}{l}\text { Host Plant } \\
\quad \text { (Part) }\end{array}$ & Endophyte Strains & Function & $\begin{array}{l}\text { Next Generation } \\
\text { Sequencing } \\
\text { Platform }\end{array}$ & Reference \\
\hline $\begin{array}{l}\text { Sorghum bicolor } \\
\text { (roots, stems) }\end{array}$ & $\begin{array}{c}\text { Duganella, Aquabacterium, Bordetella, } \\
\text { Massilia, } \\
\text { Pantoea, } \\
\text { Salmonella, Klebsiella, Kosakonia, Pseudomonas, } \\
\text { Serratia, Stenotrophomonas, } \\
\text { Agrobacterium, Ancylobacter, } \\
\text { Brevundimonas, Pleomorphomonas, } \\
\text { Curtobacterium, Microbacterium, Nocardia, } \\
\text { Sediminihabitans } \\
\text { Bacillus, Macrococcus, Staphylococcus, } \\
\text { Exiguobacterium }\end{array}$ & $\begin{array}{c}\text { PGP abilities. } \\
\text { Production of hormones. } \\
\text { Synthesis of fungicides } \\
\text { and bactericides. Ability } \\
\text { to supply nitrogen to } \\
\text { plants. }\end{array}$ & Ion Torrent PGM & [17] \\
\hline $\begin{array}{l}\text { Sorghum bicolor L. } \\
\text { Moench (stems, } \\
\text { roots) }\end{array}$ & $\begin{array}{c}\text { Microbacterium, Agrobacterium, } \\
\text { Sphingobacterium, Herbaspirillum, Erwinia, } \\
\text { Pseudomonas, Stenotrophomonas }\end{array}$ & PGP abilities & $\begin{array}{l}\text { Roche } \\
\text { 454-pyrosequencing }\end{array}$ & [23] \\
\hline $\begin{array}{l}\text { Pinus arizonica } \\
\text { Pinus durangensis } \\
\text { (roots, phloem, } \\
\text { bark) }\end{array}$ & $\begin{array}{c}\text { Thermi, } \\
\text { Tenericutes } \\
\text { Acetobacter, Burkholderia, Caulobacter, } \\
\text { Pseudomonas, Ralstonia, Bradyrhizobium, } \\
\text { Metylocapsa }\end{array}$ & $\begin{array}{l}\text { Biosynthesis of } \\
\text { secondary metabolites. } \\
\text { Metabolism of cofactors } \\
\text { and vitamins }\end{array}$ & $\begin{array}{l}\text { Roche } \\
\text { 454-pyrosequencing }\end{array}$ & [24] \\
\hline $\begin{array}{l}\text { Vitis vinifera cv. } \\
\text { Summerblack } \\
\quad \text { (stems) }\end{array}$ & $\begin{array}{c}\text { Acremonium, } \\
\text { Alternaria, Arthrinium, Ascorhizoctonia, } \\
\text { Aspergillus, Aureobasidium, Bipolaris, } \\
\text { Botryosphaeria, Botrytis, Chaetomium, } \\
\text { Cladosporium, Curvularia, Hypoxylon, } \\
\text { Lasiodiplodia, Mycosphaerella, Nigrospora, } \\
\text { Penicillium, Phoma, Scopulariopsis }\end{array}$ & $\begin{array}{l}\text { Prevention against some } \\
\text { fungal diseases }\end{array}$ & Illumina HiSeq2500 & [35] \\
\hline $\begin{array}{l}\text { Vitis vinifera } \mathrm{L} \text {. } \\
\text { (field shoots and } \\
\text { callus tissues) }\end{array}$ & $\begin{array}{l}\text { Actinobacteria Proteobacteria Firmicutes } \\
\text { Bacteroidetes Deinococcus-Thermus }\end{array}$ & $\begin{array}{l}\text { Carbohydrate protein } \\
\text { and amino acid } \\
\text { metabolism. } \\
\text { Synthesis/conversion/ } \\
\text { utilization of nucleosides } \\
\text { and nucleotides }\end{array}$ & Illumina HiSeq & [36] \\
\hline $\begin{array}{l}\text { Cinnamomum cassia } \\
\text { Presl (roots) }\end{array}$ & Streptomyces & $\begin{array}{l}\text { Antibiotic biosynthetic } \\
\text { pathways. Antimicrobial } \\
\text { and cytotoxic properties. } \\
\text { PGP abilities. }\end{array}$ & Ion Torrent PGM & [14] \\
\hline Populus spp. & Mortierella & $\begin{array}{l}\text { PGP abilities: improved } \\
\text { growth and drought } \\
\text { tolerance }\end{array}$ & $\begin{array}{l}\text { Illumina HiSeq } \\
\text { platform }\end{array}$ & [37] \\
\hline $\begin{array}{l}\text { Ophiopogon } \\
\text { japonicas }\end{array}$ & Bacillus & $\begin{array}{l}\text { PGP abilities: oxidative } \\
\text { stress, drought tolerance, } \\
\text { heavy metal resistance }\end{array}$ & Illumina HiSeq & [38] \\
\hline $\begin{array}{l}\text { Tephrosia apollinea } \\
\text { (leaves) }\end{array}$ & Sphingomonas & Drought tolerance & $\begin{array}{l}\text { Single Molecule } \\
\text { Real Time (SMRT) }\end{array}$ & [39] \\
\hline Grasses (roots) & Actinobacteria & PGP abilities & Agilent 2100 & [40] \\
\hline
\end{tabular}

Recently, Akinsanya et al. [11] used NGS (mainly the Illumina method) for a metagenomic study of endophytes in Aloe vera and an assessment of their microbial diversity, whilst Yaish et al. [8] conducted metagenomic studies of endophytes inhabiting Medicago truncatula roots. They found that Proteobacteria, Actinobacteria, Bacteroidetes were the dominant phyla of bacteria, and Firmicutes dominated in Aloe vera. In addition, it has been evidenced that most endophytes colonize the roots of the plant, while the Pseudomonas genus and unclassified Pseudomonadaceae predominate in the shoots [11]. In turn, Annapurna et al. [33] analyzed the genome of the KMS80 strain Bacillus paralicheniformis while using the NGS technique, which made it possible to understand the process of endophytic nitrogen 
fixation and the positive effect on plant growth and crop yields. Many studies recently published studies used NGS for the determination of the plant growth promoting properties of endophytes $[13,16,17,32,33]$. NGS evidenced that endophytic representatives of the following bacterial genera: Bacillus, Paenibacillus, Rhizobium, Duganella, Serratia, Klebsiella, Agrobacterium, Microbacterium, Sphingobacterium, Erwinia, Herbaspirillum, etc. were the most effective in plant growth promotion $[13,17,23,33]$.

NGS is also applied in the identification of endophytic fungi. König et al. [41] have evidenced that such taxa as Acremonium, Alternaria, Cladosporium, Epicoccum, and Penicillium inhabit many grass species. Bullington and Larkin [42] have shown that fungal endophytes affect the survival of trees and influence the severity of their diseases. For this purpose, seedlings of Pinus monticola were inoculated with desired endophytes to ensure the protection of the microbiome and increase the defence against pathogens. Next, the endophytic fungal communities and their diversity were characterized while using NGS, and the interspecies competition was examined [42]. Moreover, it was assumed that the ability to identify fungi that cannot be grown in vitro is a great advantage of NGS [30].

\section{Biosynthesis of Factors Stimulating Plant Growth}

It has been observed that plants that are associated with endophytes can exhibit more promoted growth and higher crop yields, while those that are not associated with endophytes more weakly grow $[38,43]$. Plant growth promoting bacteria (PGPB) can be defined as representatives of biota that can stimulate the growth of the host, for example, rhizobacteria, when they grow in association with host plants $[13,43,44]$. Endophytic organisms can stimulate and intensify plant growth through the following mechanisms $[16,17,24]$ :

(a) production of phytohormones and osmolytes,

(b) increased uptake of nitrogen, and

(c) production of siderophores (molecules with a capability of binding and storage of e.g., iron, copper) and vitamins.

The potential for stimulation of plant growth by endophytic microbiota can be a model for the use of these advantageous features in biotechnology and agriculture. Endophytic organisms have the ability to produce plant hormones and regulate the synthesis thereof.

Phytohormones are signal molecules that coordinate cellular activities and control plant growth and development [45]. The best-known phytohormones that are produced by endophytic microbiota is indole-3-acetic acid (IAA), which is synthesized via the indole-3-pyruvate(IPyA) pathway [45-49]. Based on 16S rRNA gene sequence analysis, bacterial isolates effectively producing IAA were identified as Psychrobacillus, Microbacterium, Lysinibacillus, Pseudomonas, and Bacillus [44,49]. High IAA content that resulted in increased root and shoot biomass of sugarcane was evidenced in the case of Acetobacter diazotrophicus [50]. Moreover, UmaMaheswari et al. [51], who identified Micrococcus, Flavobacterium, and Serratia in various tropical grain legume crops (i.e., cowpea, chickpea), confirmed the production of IAA. Zúñiga et al. [47] presented an engineered device for IAA production under quorum-sensing signals, which enables Cupriavidus pinatubonensis JMP134 to stimulate plant growth. This device was implemented in JMP134 for synthesis of IAA in an auto-regulated manner, thus improving the growth of roots of inoculated Arabidopsis thaliana. The authors used the neutral (non PGPR-Plant Growth Promoring Rhizobacterium) Cupriavidus pinatubonensis JMP134 as a host and a regulatory forward loop that triggers the synthesis of indole-3-acetic acid (IAA) in a manner dependent on quorum-sensing (QS) signals. This new solution not only demonstrated the value of the designed genetic module, but also validated C. pinatubonensis JMP134 as a suitable vehicle for agricultural applications, as it is suitable for genetic manipulations [47].

It was also evidenced that endophytic isolates effectively produced gibberellic acid (GA) and cytokinin [51]. It is worth mentioning here that GA is an endogenous plant growth regulator that promotes i.e., stem and root elongation and flowering and/or helps to overcome dormancy in seeds [32,51]. In turn, cytokinins are a class of plant hormones that play a crucial role during the cell cycle, i.e., they are able to induce the plant cell division process and, consequently, influence the 
formation and relative growth of roots and shoots [32,51]. Abscisic acid (ABA), which is considered as a plant stress hormone, is responsible for many kinds of stresses, including water, salt, and cold temperatures [45]. What is more, salicylic acid (SA) is also known as a critical plant hormone that is involved in various processes, such as seed germination, root initiation, floral induction, and thermogenesis, besides plant tolerance to biotic and abiotic stresses [45].

Another significant benefit of endophytes, which are important in the agricultural aspect, is their capability of nitrogen $(\mathrm{N})$ fixation. The biological $\mathrm{N}$ fixation is a way of eliminating the use of chemical fertilizers and preventing damage to the agricultural ecosystem [21]. In the literature, there are some reports on $\mathrm{N}$ fixation by the legume plant-rhizobium system [52-54]. Additionally, information regarding $\mathrm{N}$ fixation by non-legume plants and bacteria other than rhizobia is also available $[16,33,55]$. Sphingomonas azotifigens was a novel bacterium that was reported for the first time as $\mathrm{N}$ fixing bacteria from India. In turn, Stenotrophomon asmaltophila and Herbispirillum rubrisubalbicans had been noted earlier as plant pathogens, but they showed high potential for $\mathrm{N}$ fixation and the production of auxins $[40,45]$. Aryantha and Hidiyah [56] determined the colonization of diazotroph endophytic bacteria on oil palm leaves (Elaeis guineensis Jacq L.) and found that Bacillus cereus displayed the highest nitrogen fixation capability. The ability of $\mathrm{N}$ fixation was also confirmed in the case of Exiguobacterium profundum strain N4 colonizing Amaranthus spinosus [57], Rhizobium, Sphingomonas, Azospirillum, and Grobacterium inhabiting wild rye tissues [58].

Another widespread characteristic among endophytes is the ACC (1-aminocyclopropane-1-carboxylic acid) deaminase activity [53]. The rRegulation of ACC is known as a principal mechanism by which bacteria exert beneficial effects on abiotically stressed plants [51]. Importantly, endophytes that possess this enzyme can use the ethylene precursor ACC as a source of N [53]. The ethylene content in plants decreased via the bacterial hydrolysis of ACC, and finally the root growth increased $[53,59,60]$. It was discovered that bacteria belonging to the genera of Bacillus and Pseudomonas had the highest AAC deaminase activity [61], as well as representatives of Enterobacter, Stenotrophomonas, Pantoea [62], Achromobacter, and Variovorax [53].

Endophytic biota also has an ability to produce low-molecular weight secondary metabolites, i.e., phytohormones or their precursors-vitamins B12 [63] and B1 [64]. Other authors have reported that Bacillus subtilis CBR05 induces vitamin B6 biosynthesis in tomato [65]. Vitamin B6 possesses antioxidant activity and it can modulate plant defense by regulating the antioxidant status in plants [65]. Black et al. [66] have evidenced that vitamin D can also be biosynthesised in plants, as many of them are colonized by endophytic fungi, which have cell membranes that contain ergosterol [67]. Thus, vitamin D2 in plants has been found to be a result of photoconversion of ergosterol in these fungal contaminants [66]. Vitamin D3 has been mainly found in the Solanaceae family in research focused on the leaves [66]. Interesting observations were reported by Flores-Felix et al. [68], who indicated a significantly higher (almost double) vitamin $C$ content in strawberry fruits from plants that were inoculated with bacterial strain Phyllobacterium PEPV15 than in fruits from uninoculated plants. Therefore, it might be assumed that the inoculation with strain PEPV15 increases the yield, quality, and functionality of strawberry fruit [68].

In nearly all living organisms, iron $(\mathrm{Fe})$ is mentioned as a required essential trace element. Fe is not freely available in living tissues due to its insolubility and toxicity in aerobic environments. Under Fe starvation, most microorganisms synthesize siderophores-low-molecular weight iron-chelating agents that solubilize Fe (III) and control intracellular Fe levels [69]. Liaqat and Eltem [70] identified the following species: Brevundimonas diminuta, Leifsonia shinshuensis, Sphingomonas parapaucimobilis, Brevundimonas vesicularis, and Agrobacterium tumefaciens as endophytes that are able to produce siderophores. Earlier, it was evidenced that Methylobacterium phyllosphaerae (isolated from the phyllosphere of lowland rice, India) produced a hydroxamate type of siderophores during Fe starvation, as well as tryptophan and tyrosine [69]. It has also been documented that most Streptomyces species produce siderophores with diverse structural backgrounds [53]. Moreover, siderophore production is one of the mechanisms by which Streptomyces can exert beneficial effects on plant growth [71]. 
Bacillus sp., Pseudomonas sp., and Stenotrophomonas sp. were identified as other known endophytic bacterial isolates that are effective in siderophore production [72].

\section{Endophytic Strains Applied for Commercial-Scale Production as Biofertilizers and Biopreparations}

Nowadays, there is a search for microbial strains that can be used for the development of bioinoculants, biofertilizers, and biopreparations enhancing the growth and yield of crop plants. Table 2 presents the biotechnological and agricultural aspects that are connected with applications of some endophytes as the main components for the production of biofertilizers and biopreparations.

Biopreparations are products that originate from either living organisms or their metabolites [3]. They are dedicated to being applied in organic farming, as they increase crop yields and decrease environmental stresses [3,73]. These products are mainly recommended for combating pathogens, increasing plant resistance to low temperatures, protecting seeds, enhancing plant nutrient uptake, and improving plant vigor [3]. To date, Bacillus strains, followed by Thiobacillus species, have been applied in most commercially available bio-preparations. However, such endophytic strains as Trichoderma, Pseudomonas, Azospirillum, Rhizobium, and Gluconacetobacter have also been evidenced as effective for use in the composition of bio-preparations (Table 2).

Table 2. Examples of endophytic strains applied for commercial-scale production as biofertilizers and biopreparations.

\begin{tabular}{|c|c|c|c|}
\hline Preparation Name & Composition & Function & Reference \\
\hline Phytosporin-M & Bacillus subtilis 26D & \multirow{3}{*}{$\begin{array}{l}\text { Displacement of pathogenic } \\
\text { fungi and stimulation of } \\
\text { plant growth }\end{array}$} & \multirow{3}{*}{ [74] } \\
\hline Albit & $\begin{array}{l}\text { B. subtilis } 2604 \mathrm{D}+\text { B. subtilis } \\
2605 D+\text { terpene acids, macro- } \\
\text { and microelements }\end{array}$ & & \\
\hline Vitaplan & $\begin{array}{l}\text { B. subtilis } 2604 \mathrm{D}+\text { B. subtilis } \\
2605 \mathrm{D}\end{array}$ & & \\
\hline Alirin-B & B. subtilis & $\begin{array}{l}\text { Reduction of the number of } \\
\text { micromycetes }\end{array}$ & \multirow{3}{*}{ [75] } \\
\hline Trianum $\mathrm{P}$ & Trichoderma harzianum T-22 & $\begin{array}{l}\text { Fungicidal effect. } \\
\text { Stimulation of tobacco } \\
\text { seedling growth }\end{array}$ & \\
\hline Cedomon EO & Pseudomonas chlororaphis MA 342 & $\begin{array}{l}\text { Protection of barley seeds } \\
\text { against Pyrenophora graminea, } \\
\text { Fusarium spp., and Bipolaris } \\
\text { sorokiniana }\end{array}$ & \\
\hline Cropaid & $\begin{array}{c}\text { Thiobacillus thiooxidans, } \\
\text { T. thioparus, T. ferrooxidans and } \\
\text { over } 60 \text { minerals }\end{array}$ & $\begin{array}{l}\text { Stimulation of production of } \\
\text { proteins and amino acids } \\
\text { that increase plant resistance } \\
\text { to cold and frost damage }\end{array}$ & [76] \\
\hline $\begin{array}{c}\text { Symbion-N } \\
\text { Symbion-NG } \\
\text { Symbion-NR } \\
\text { Bio-cure B } \\
\text { Bio-cure F } \\
\text { Bio-health WGP } \\
\text { Rhizo-N }\end{array}$ & $\begin{array}{c}\text { Azospirillium lipoferum } \\
\text { Gluconacetobacter diazotrophicus } \\
\text { Rhizobium phaseoli } \\
\text { Pseudomonas fluorencese } \\
\text { Trichoderma viridi } \\
\text { Bacillus megatherium } \\
\text { Trichoderma larizianum } \\
\text { Bacillus subtilis }\end{array}$ & $\begin{array}{l}\text { Restriction of the } \\
\text { pathogenicity of fungi } \\
\text { Fusarium solani and } \\
\text { Rhizoctonia solani. } \\
\text { Support of plant } \\
\text { development and vigor }\end{array}$ & {$[77]$} \\
\hline
\end{tabular}

Endophytic isolates were also tested as bioinoculants to potato tubers and were recommended as biofertilizers reducing the dependence on chemical fertilizers [48], which was extremely important from the agricultural point of view. Biofertilizers are defined as substances that contain living organisms that, when applied to seeds, plant surfaces, or soil, colonize the rhizosphere or the plant interior 
and promote growth by increasing the supply or availability of primary nutrients to the host [78]. For example, Mwajita et al. [79] isolated the microorganisms from Kenyan rice (Oryza sativa L.), which were positive for phosphate solubilization, nitrogenase activity, and IAA production. Hence, these microorganisms can be potentially used as biofertilizers in rice production. This solution is very important in Kenya, given the major problem that is related to the declining soil fertility, which is currently limited due to the rising costs and environmental concerns. Generally, the most common bacteria, such as Azospirillum, Herbaspirrilum, Acetobacter, Azotobacter, and Azoarocus, are successfully used as biofertilizers [53]. Additionally, other autochthonic bacterial species present in the soil environment (Bacillus, Streptomyces, and Pseudomonas) that exert a positive effect on plant biofertilization can be developed for commercialization [53]. Therefore, the search for biofertilizers might provide an alternative to chemical fertilizers for the achievement of sustainable rice farming accompanied by the improvement of productivity in the rice agroecosystem.

The fact that inoculation of plants with endophytes usually results in an effective decrease in fungal, bacterial, and viral diseases, and reduces damage that is caused by insects and nematodes has been broadly studied [80-86]. Gai et al. [83] isolated bacterial communities associated with the heads of surface-sterilized insect vectors of X. fastidiosa subsp. pauca that were collected from citrus variegated chlorosis affecting citrus groves in Brazil. The authors identified the citrus endophytes as Methylobacterium spp. and Curtobacterium spp based on amplified ribosomal DNA restriction analysis (ARDRA) and sequencing. It appeared that these bacteria had high frequencies in sharpshooters [83]. This study represented a new basis for the knowledge of the interaction of symbiotic-pathogenic bacteria inside insect vectors and provided a basis for further work regarding the biocontrol of plant bacteria like X. fastidiosa [83].

\section{Studies of Improvement of Ecological Adaptation of the Host in Salinity and Drought Conditions}

It was earlier emphasized that the endophyte microbiota is able to use several mechanisms to stimulate drought stress tolerance in plants $[46,80,87]$, as they can:

(a) produce auxin (IAA), gibberellins, cytokinins in order to maintain plant hormone homeostasis,

(b) produce ACC in order to control the ethylene content (plant stress phytohormone),

(c) decrease the content of reactive oxygen species by manipulating the activities of plant antioxidant enzymes,

(d) release osmoprotectants in stress conditions,

(e) produce exopolysaccharides protecting plant roots against desiccation, and

(f) help in solubilization of poorly available nutrients for plant roots (e.g., $\mathrm{Fe}, \mathrm{P}$ ).

Endophytes can confer habitat-adapted tolerance to the host plant and receive some benefits, i.e., nutrient availability and protection from the host plant $[88,89]$. The host-endophyte relationships can usually take three forms: mutualism, commensalism, and parasitism [88,90,91].

Salt stress usually induces osmotic and ionic imbalance inside plant cells $[8,92,93]$. In unfavorable conditions, endophytes reduce stress in plants by synthesizing osmoprotectants, e.g., proline and/or trehalose, volatile organic molecules, and exopolysaccharides [8]. It has also been proven that PGP endophytes (Pseudomonas fluorescens YsS6 and Pseudomonas migulae 8R6) that contain ACC deaminase (E.C.4.1.99.4) can reduce salt stress in tomato plants [43]. Similar features have also been described in the case of Enterobacter sp. [8]. Moreover, it was observed that plants that were pretreated with ACC deaminase in salt stress conditions displayed higher chlorophyll contents, as well as higher dry and fresh biomass, and produced a greater number of flowers [43]. In response to salinity, Gammaproteobacteria, Betaproteobacteria, Flavobacteria, and Streptomycetales were found to dominate [8]. Other authors reported that bacterial B. cereus and B. aerius strains are valuable biological plant growth promoters that are able to enhance salt tolerance in safflower plants in plant growth and the ascorbate glutathione redox cycle, in comparison with the non-inoculated controls [94]. It was indicated that the co-inoculation of the selected endophytic bacterial strains that were successfully isolated from the safflower seedlings 
significantly alleviated the harmful effects of salt stress and promoted plant growth and biomass yield [94].

By isolation of fungal endophytes from the roots of soybean, Latif et al. [93] observed that Penicillium minioluteum LHL09 in the endophyte-plant interaction significantly improved soybean growth properties (i.e., shoot fresh and dry biomass, shoot length, leaf area, and chlorophyll concentration) and nitrogen assimilation in salt stress conditions. Moreover, the results from scanning electron microscope (SEM) observations proved the active colonization of the host plant by the endophyte both before and after the salt stress treatment [90]. Min et al. [88] studied the endophytic diversity in Pinus thunbergii roots from three coastal regions of Korea. It is worth mentioning here that the ability to resist high salinity stress is essential for surviving in coastal environments. Endophytes exhibiting saline resistance were classified as Penicillium, Trichoderma, Acremonium variecolor, Aspergillus sydowii, and Myxotrichum stipitatum [88].

In both agricultural and natural niches, plants encounter a combination of abiotic conditions, including drought and/or heat shock stress [95-98]. The tolerance to drought stress is often explained by enhanced accumulation of several solutes (i.e., osmolytes) in tissues of endophyte-infected plants and/or by reduced leaf conductance and the formation of a thicker cuticle $[99,100]$. The perennial ryegrass (Lolium perenne) is a cool-season grass species and it is one of the most important forage, pasture, and turf grasses. Its characteristic feature is the fact that it is often infected by the leaf-inhabiting endophyte Neothypodium lolii [85]. The results that are presented by Kane [96] clearly demonstrated that infection with this endophyte usually helps to survive drought stress. The author also observed changes in the morphological growth response (tiller length) of the host plant in the presence of N. lolii [96].

Fungal endophytes are considered to be plant mutualists and they obligate biotrophs [96]. Hubbard et al. studied the effect of the symbiosis of fungal endophytes on the growth of plant exposed to heat and drought stress [97]. The authors observed that endophytic fungi (Asco-, Basidiomycota) increased plant tolerance to drought and heat and contributed to a higher level of plant antioxidant enzymes [97]. Recently, Dastogeer et al. [101] studied how endophytes that were isolated from wild Nicotiana species improved water stress tolerance in $N$. benthamiana plants. They noted that water stress tolerance of fungus-inoculated plants was positively correlated with an increase in many factors, e.g., plant biomass, proline content, soluble sugars and proteins, and activities of antioxidant enzymes (catalase, peroxidase, polyphenol oxidase). The up-regulation of genes known to be drought induced was also confirmed [101]. Drought-related genes can be divided into two major groups [102]:

(a) proteins-with function of direct stress tolerance, and

(b) regulatory proteins-involved in signal transduction or expression of stress-responsive genes.

It is also known that the transgenic over expression of plant root vacuolar proton pumps $\mathrm{H}^{+}$-ATPase (V-ATPase) and $\mathrm{H}^{+}$-PPase (V-PPase) support the tolerance to drought $[98,103,104]$. Both of these substances are considered to be key enzymes in plant response to drought, as they help plant tissues to maintain proper cell turgor in water deficit conditions [105]. Vigani et al. [98] tested two pepper strains (Capsicuum annum L.) in drought conditions and found that bacterial colonization enhanced V-PPase, an enzyme that is involved in the alleviation of drought stress.

\section{Application of Endophytes for Bioremediation, Biotransformation, and Production of Bioactive Metabolites}

The collaboration between the plant and endophytes can also play a key role in the degradation of hazardous contaminants in the rhizosphere [106]. A promising area of exploitation of the cultured and uncultured endophytic microbiota for phytoremediation, bioaugumentation, and biostimulation processes of contaminated environments has been described (Figure 2). 


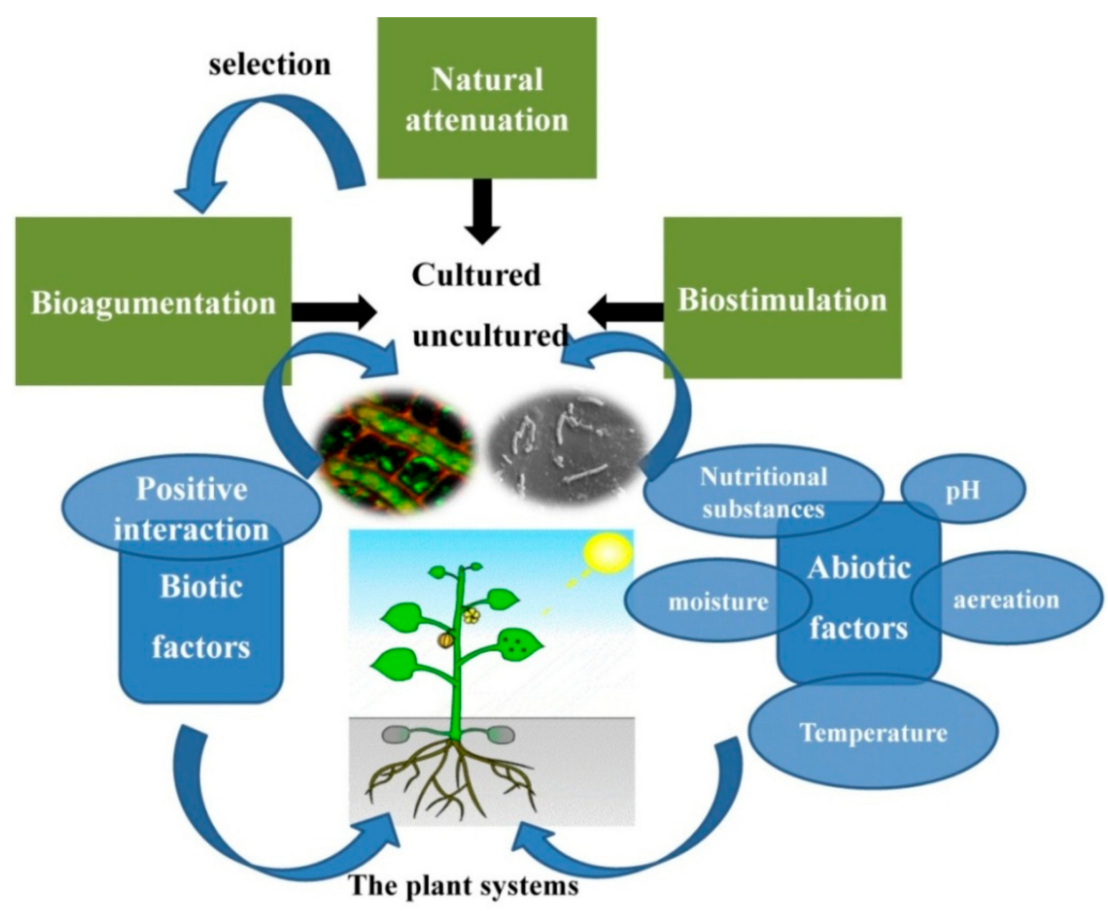

Figure 2. Biotic and abiotic factors affecting plant-microbe interactions during phytoremediation and biotransformation processes. Oval images presents plant associated endophytes seen under the fluorescence and electron microscopes (photos taken by the authors).

Phytoremediation is an alternative in situ technology that exploits plants and their rhizosphere to remove contaminants or lower their bioavailability in soil and water with concurrent land revegetation [107].

Bioaugumentation is a technique that is based on the addition of microorganisms that have the ability to biodegrade recalcitrant molecules in a polluted environment [108].

Biostimulation is a method that involves modification of the environment to stimulate existing (authochthonic) bacteria capable of bioremediation. The modification step usually includes the addition of various forms of limiting nutrients and electron acceptors, such as oxygen, nitrogen, phosphorus, or carbon (in the form of molasses), which are otherwise available in sufficiently low quantities to constrain microbial activity [109]. All of the techniques defined shortly are less costly and friendlier to the environment than physicochemical approaches [108]. Table 3 presents the current summary (limited to 2018-2020 findings) in the aspect of endophytic biota application into bioremediation and biotransformation processes.

It was evidenced that many identified endophytic strains could be applicable for either bioremediation and/or biotransformation processes (Table 3). The most effective strains for bioremediation are bacterial representatives of the following genera: Pseudomonas, Bacillus, Pantoea, Streptomyces, Klebsiella, Shewanella, Burkholderia, and Sphingomonas [110-128], fungal endophytes: Lasiodiplodia, Aspergillus, Curvularia, Westerdykella, and representatives of Lindgomycetaceae [111,121,125]. However, their application depends on the contaminants and their metabolic functions (Table 3). The following bacterial and fungal endophytes are recommended for the biotransformation of different contaminants: Flavobacterium, Pseudomonas, Enterobacter, Serratia, Arthrobacter, Ochrobactrum, Bacillus, Sphingomonas, Cellulosimicrobium, and Aspergillus. As shown in Table 3, some endophytes can be regarded as universal and effective for both bioremediation and biotransformation processes, i.e., Pseudomonas, Bacillus, Flavobacterium, and Sphingomonas. 
Table 3. Examples of endophytic strains applied for bioremediation and biotransformation processes.

\begin{tabular}{|c|c|c|c|}
\hline Process & Endophytes & Function & Reference \\
\hline \multirow{14}{*}{ 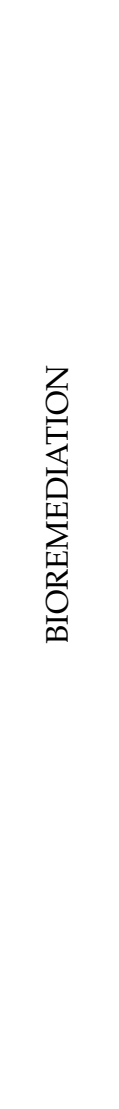 } & Pseudomonas putida & Degradation of alkanes & [110] \\
\hline & $\begin{array}{c}\text { Aspergillus sp. A31, Curvularia } \\
\text { geniculata P1, Lindgomycetaceae P87, } \\
\text { Westerdykella sp. P71 }\end{array}$ & $\begin{array}{l}\text { Reduction of mercury concentrations } \\
\text { in soil by bioaccumulation }\end{array}$ & [111] \\
\hline & Bacillus megaterium BM18-2 & Cd removal & [112] \\
\hline & Pantoea dispersa & Bisphenol A (BPA) removal & [113] \\
\hline & Bacillus safensis strain ZY16 & $\begin{array}{l}\text { Degradation of C12-C32 n-alkanes } \\
\text { from diesel oil }\end{array}$ & [114] \\
\hline & Pseudomonas sp. & Hydrocarbon degradation & [115] \\
\hline & Streptomyces sp. Hlh1 & $\begin{array}{l}\text { Degradation of petroleum } \\
\text { hydrocarbons (TPH), n-alkanes and } \\
\text { aromatic hydrocarbons }\end{array}$ & [116] \\
\hline & Pseudomonas sp. J10 & Diesel degradation & [117] \\
\hline & Bacillus megaterium YJB3 & Removal of phthalic acid esters (PAE) & [118] \\
\hline & Streptomyces & $\begin{array}{l}\text { Degradation of n-alkanes (C6-C30), } \\
\text { aromatic and polycyclic aromatic } \\
\text { hydrocarbons }\end{array}$ & [116] \\
\hline & Bacillus subtilis N-1 & Lowering PAE accumulation & [119] \\
\hline & Pseudomonas fluorescence & $\mathrm{Zn}, \mathrm{Cr}, \mathrm{Cd}, \mathrm{Ni}$ removal & [120] \\
\hline & Lasiodiplodia sp. MXSF31, Mucor sp. & Bioaccumulation of $\mathrm{Pb}, \mathrm{Cd}, \mathrm{Zn}$ & \\
\hline & $\begin{array}{c}\text { Bacillus, Klebsiella, Shewanella, } \\
\text { Burkholderia, Pseudomonas, } \\
\text { Sphingomonas }\end{array}$ & Removal of dyes & [121] \\
\hline \multirow{7}{*}{ 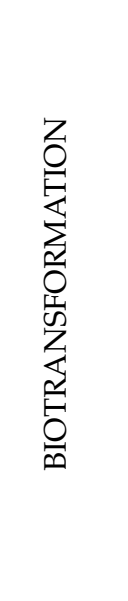 } & Flavobacterium sp. GE 32 & $\begin{array}{l}\text { Biotransformation of ginsenoside Rb1 } \\
\text { to Gyp-XVII and ginsenoside Rg3 }\end{array}$ & [122] \\
\hline & Pseudomonas sp. Ph6-gfp & Biotransformation of phenanthrene & [123] \\
\hline & $\begin{array}{c}\text { Enterobacter sp., Serratia sp., } \\
\text { Ochrobactrum sp., Arthrobacter sp. }\end{array}$ & $\begin{array}{l}\text { Biotransformation of ginsenoside Rb1 } \\
\text { to ginsenoside Rd and Rg3 }\end{array}$ & [124] \\
\hline & Aspergillus flavus & $\begin{array}{l}\text { Biotransformation of soluble arsenic } \\
\text { into an immobilized arsenic particle }\end{array}$ & [125] \\
\hline & $\begin{array}{c}\text { Pseudomonas proteolytica FM18Mci1 } \\
\text { Bacillus sp. FM18civ1 }\end{array}$ & $\begin{array}{l}\text { Biotransformation of }(4 S)-(+) \text {-carvon } \\
\text { (1a) and (4R)-(-)-carvon (1b) }\end{array}$ & [126] \\
\hline & Sphingomonas sp. LK11 & $\begin{array}{l}\text { Biotransformation of benzoin to } \\
\text { benzamide }\end{array}$ & [127] \\
\hline & Cellulosimicrobium cellulans sp. 21 & $\begin{array}{c}\text { Biotransformation of ginsenoside } \mathrm{Rb} 1 \\
\text { into } \operatorname{Rg} 3 \text { and Re into } \operatorname{Rg} 2\end{array}$ & [128] \\
\hline
\end{tabular}

The need for new and useful biologically active compounds in medicine is constantly growing. Nowadays, bacterial drug resistance and the great genetic variability of bacteria encourage scientists to look for new antibiotics - antimicrobial compounds. On the other hand, the analysis of everyday life contributes to the search for new solutions in the field of anticancer drugs. A current scientific trend is the search for new sources of biologically active substances, i.e., natural microorganisms.

Bacterial endophytes can produce a wide range of biologically active compounds [14]:

(a) antibiotics (antimicrobial compounds),

(b) anticancer compounds, and

(c) anti-malarial compounds. 
Table 4 presents a summary of the most popular bioactive compounds synthesized by endophytic microbiota. Usually, cytotoxic activity [129-131] followed by anticancer and antibacterial activities [132-134], antiviral effects [135], and protective impact against pathogens [134] were detected.

Table 4. Examples of endophytic strains, their host plant, synthesized bioactive compounds, and functions.

\begin{tabular}{|c|c|c|c|c|}
\hline Endophyte Strains & Host Plant & Bioactive Compound & Function & Reference \\
\hline Fusarium solani & $\begin{array}{l}\text { Camptotheca } \\
\text { acuminata }\end{array}$ & Camptothecin & $\begin{array}{l}\text { Cytotoxic activity against } \\
\text { cancer cells }\end{array}$ & [129] \\
\hline Cladosporium sp. & Taxus baccata & Taxol & $\begin{array}{l}\text { Antimitotic effect on } \\
\text { MCF-7 cells in a human } \\
\text { breast cancer cell line }\end{array}$ & [130] \\
\hline $\begin{array}{l}\text { Gibberella } \\
\text { moniliformis }\end{array}$ & Lawsonia inermis L. & Lawsone & $\begin{array}{l}\text { Synthesis of natural dye } \\
\text { with antioxidant, antiviral, } \\
\text { antidermatophytic, } \\
\text { tuberculostatic, and } \\
\text { cytotoxic enzymes activity }\end{array}$ & [131] \\
\hline Aspergillus flocculus & $\begin{array}{l}\text { Markhamia } \\
\text { platycalyx }\end{array}$ & $\begin{array}{l}\text { cis-4-hydroxymellein, } \\
\text { 5-hydroxymellein, } \\
\text { diorcinol, } \\
\text { botryoisocoumarin A, } \\
\text { mellein }\end{array}$ & $\begin{array}{l}\text { Bioactive anticancer and } \\
\text { anti-trypanosome } \\
\text { properties }\end{array}$ & [132] \\
\hline $\begin{array}{c}\text { Daldinia } \\
\text { eschscholtzii A630 }\end{array}$ & Pogostemon cablin & $\begin{array}{c}\text { Eschscholin A, } \\
\text { 3-ene-2-methyl-2H- } \\
\text { 1-benzopyran-5-ol, } \\
\text { 3,5-dihydroxy-2- } \\
\text { methyl-4H-chromen- } \\
\text { 4-one }\end{array}$ & Antibacterial activities & [133] \\
\hline $\begin{array}{l}\text { Dimorphosporicola } \\
\text { tragani CF- } 090383\end{array}$ & $\begin{array}{l}\text { Arthrocnemum } \\
\text { macrostachyum }\end{array}$ & Cerulenin & $\begin{array}{l}\text { Inhibition of fatty acid } \\
\text { synthesis }\end{array}$ & [136] \\
\hline $\begin{array}{c}\text { Jishengella } \\
\text { endophytica } 16111\end{array}$ & $\begin{array}{l}\text { Xylocarpus } \\
\text { granatum }\end{array}$ & Perlolyrine & Antiviral effect & [135] \\
\hline $\begin{array}{l}\text { Streptomyces sp. } \\
\text { TP-A0569 }\end{array}$ & Allium fistulosum & Fistupyrone & $\begin{array}{l}\text { Plant protection against } \\
\text { pathogenic fungi }\end{array}$ & \\
\hline $\begin{array}{l}\text { Streptomyces sp. } \\
\text { TP-A0556 }\end{array}$ & Aucuba japonica & $\begin{array}{c}\text { Coumarins TPU-0031-A } \\
\text { and B }\end{array}$ & $\begin{array}{l}\text { Antibiotic activity against } \\
\text { Gram-positive and } \\
\text { Gram-negative bacteria }\end{array}$ & [134] \\
\hline $\begin{array}{c}\text { Streptomyces } \\
\text { hygroscopicus } \\
\text { TP-A0451 }\end{array}$ & Pteridium aquilinum & $\begin{array}{c}\text { Pteridic acids A and B, } \\
\text { Pterocidin }\end{array}$ & $\begin{array}{l}\text { Plant growth-promoting } \\
\text { properties }\end{array}$ & \\
\hline
\end{tabular}

Many such cases have been documented in literature older than from the last two years are included in Table 4. For example, Ramalingam and Amutha [137] isolated endophytic bacteria from Jania rubens and Gracilaria corticata. It appeared that bacteria associated with the seaweeds had antibacterial activity against three pathogenic bacteria of poultry: Escherichia coli, Pausterella multocida, and Salmonella pullorum and three pathogenic bacteria of cattle: E. coli, Staphylococcus aureus, and Pseudomonas aeruginosa. Therefore, they are recommended for use in the treatment of poultry and cattle diseases [136]. De Melo et al. [138] isolated bacterial endophytes that belonged to the Bacillus genus. B. pumilus MAIIIM4a exhibited strong inhibitory activity against the fungi Rhizoctonia solani, Pythium aphanidermatum, and Sclerotium rolfsii [135]. After LC/MS analysis, it appeared that B. pumilus MAIIIM4a produced an antifungal compound, which was identified as pumilacidin [138]. Narayan et al. [134] tested endophytic isolates against plant pathogens (Alternaria panax, Botrytis cinerea, Colletrotichum acutatum, Fusarium oxysporum, and Phytophthora capsici). With the use of $16 \mathrm{~S}$ rDNA gene sequencing, they detected the following genera exerting this effect: Pseudomonas, Bacillus, Burkholderia, Actinobacter, Arthrobacter, Enterobacter, Escherichia, Kitasatospora, Pandoraea, Pantoea, Rhizobium, Ralstonia, Paenibacillus, and Serratia [139]. 
In the literature database, some endophytic Actinomycetes strains have been described to have the ability to produce bioactive compounds that inhibit some pathogenic fungi and bacteria. The first peptide antimycotics, termed ecomycins, originated from a plant-associated bacterium Pseudomonas viridiflava [140]. The ecomycins had significant bioactivities against a wide range of human and plant pathogenic fungi [140].

Shenpagam et al. [141] isolated endophytic Actinomycetes from medicinal plants Azadiracta indica, Ocimum sanctum, and Phyllanthus amarus. Their bioactive compounds exhibited activity against bacterial pathogens Staphylococcus aureus, Streptococcus pyogenes, Klebsiella pneumonia, and Pseudomonas aeruginosa, and the fungus Rhizopus [141].

\section{The Role of Endophytes in Support of Defense Mechanisms in Plants}

An important agricultural function of endophytes is to support plants in defense mechanisms against pathogens. Table 5 summarizes the latest achievements in this field, including the host plant, endophytic strain, and type of interaction.

Table 5. Examples of endophytic strains, their host plant, synthesized bioactive compounds, and functions.

\begin{tabular}{|c|c|c|c|}
\hline Host Plant & Endophytes & Type of Interaction & Reference \\
\hline $\begin{array}{c}\text { Maize } \\
\text { Zea mays } \mathrm{L} . \\
\text { Indian popcorn }\end{array}$ & $\begin{array}{l}\text { Bacillus spp. } \\
\text { Bacillus amyloliquefaciens }\end{array}$ & $\begin{array}{l}\text { Antifungal lipopeptides (Iturin A, } \\
\text { Bacillomycin, Fengycin) induce the } \\
\text { up-regulation of pathogenesis-related genes } \\
\text { of host plants } \\
\text { Gene expression induced by jasmonic acid }\end{array}$ & {$[142]$} \\
\hline $\begin{array}{l}\text { Tomato } \\
\text { Solanum lycopersicon } \\
\text { Hezuo903 }\end{array}$ & Bacillus cereus BCM2 & $\begin{array}{l}\text { Induction of phenylalanine ammonia-lyase } \\
\text { genes (defense system) }\end{array}$ & [144] \\
\hline Arabidopsis thaliana & $\begin{array}{l}\text { Arthrobacter endophyticus } \\
\text { SYSU 33332, Nocardiopsis } \\
\quad \text { alba SYSU } 333140\end{array}$ & $\begin{array}{l}\text { Induction of up-regulated water and } \\
\text { potassium ion uptake, chlorophyll a } \\
\text { reductase, peptidemethionine (R)-S-oxide } \\
\text { reductase genes during salt stress }\end{array}$ & [145] \\
\hline $\begin{array}{l}\text { Medicinal herb } \\
\text { Atractylodes lancea }\end{array}$ & Gilmaniella sp. AL12 & $\begin{array}{l}\text { Induction of down-regulated plant } \\
\text { immunity genes and up-regulated primary } \\
\text { metabolism (carbon fixation, carbohydrate } \\
\text { metabolism, and energy metabolism) genes }\end{array}$ & [146] \\
\hline $\begin{array}{c}\text { Cacao } \\
\text { Theobroma cacao }\end{array}$ & $\begin{array}{l}\text { Colletotrichum tropicale } \\
\text { strain } 5101 \text { CBS } 124949\end{array}$ & $\begin{array}{l}\text { Up- and down-regulation of scores of host } \\
\text { genes involved in defense against biotic } \\
\text { stresses (i.e., pathogens and herbivores, } \\
\text { ethylene signaling, and defense response } \\
\text { pathways) as well as signaling proteins } \\
\text { (i.e., receptor kinases) }\end{array}$ & [147] \\
\hline $\begin{array}{l}\text { Barley } \\
\text { Hordeum vulgare } \\
\text { L. cv Golden Promise, } \\
43 \text { hereafter } \mathrm{Hv}\end{array}$ & Serendipita vermifera & $\begin{array}{l}\text { Induction of expression encoding } \\
\text { hydrolytic enzyme genes, reduction of } \\
\text { pathogen infection }\end{array}$ & [148] \\
\hline $\begin{array}{c}\text { Maize } \\
\text { Zea mays L. B73 }\end{array}$ & Trichoderma virens & $\begin{array}{l}\text { Regulation and modulation of } \\
\text { phytohormones and cell wall degrading } \\
\text { encoding genes }\end{array}$ & [149] \\
\hline $\begin{array}{l}\text { Tall fescue Festuca } \\
\text { arundinacea vr. Schreb }\end{array}$ & $\begin{array}{l}\text { Endophytic nontoxic strain } \\
\text { NTE } 19\end{array}$ & $\begin{array}{c}\text { Induction of stress pathways in response to } \\
\text { water deficit }\end{array}$ & [150] \\
\hline
\end{tabular}

It has been evidenced that both endophytic bacterial representatives (Bacillus, Arthrobacter, Nocardiopsis) and fungal endophytes (Gilmaniella, Colletotrichum, Serendipita, Trichoderma) support the defense mechanisms in plants and, consequently, their presence is extremely desirable from the agricultural point of view (Table 5).

Gond and coworkers [142] hypothesized that bacterial endophytes naturally occurring in many maize varieties protect the host organism by secreting antifungal lipopeptides (iturin A, bacillomycin, 
fengycin) that inhibit pathogens. They can also induce the up-regulation of pathogenesis-related genes of host plants (known as systemic acquired resistance). In another publication [143], the same authors reported that jasmonic acid-induced gene expression was greater in the pathogen-challenged plants that were pre-treated with the endophytic bacterium (Bacillus) than in plants only challenged with the pathogen. Finally, it was assumed that the expression of pathogenesis-related genes (PR-1 and PR-10) was significantly induced by B. amyloliquefaciens subsp. subtilis in response to the pathogen infection [143].

The activation of defense-related enzymes after the addition of endophytic bacteria Bacillus cereus BCM2 against the nematode Meloidogyne incognita parasite of tomato were tested by $\mathrm{Hu}$ et al. [144], who revealed that the plant-pathogen interaction pathway was significantly enriched for B. cereus BCM2-mediated M. incognita resistance [144].

Transcriptomic analysis that was performed by Dong et al. [145] proved that bacterial genes were responsible for water and potassium ion uptake, chlorophyll a reductase, and peptidemethionine (R) -S-oxide reductase were up-regulated when Arabidopsis thaliana grew under salt stress and were inoculated with two endophytic strains (Arthrobacter endophyticus and Nocardiopsis alba). These authors also observed that carotenoid and phenylpropanoid biosynthesis, as well as phenylalanine, glycerolipid, and nitrogen metabolism, played a crucial role in enhancing salt stress tolerance in A. thaliana [145].

The results that were obtained by Yuan et al. [146] demonstrated that genes and proteins related to primary metabolism (carbon fixation, carbohydrate, and energy metabolism) tended to be up-regulated in the presence of a fungal endophyte (Gilmaniella), as well as genes involved in terpene skeleton biosynthesis. The activation of host (Cacao) genes involved in defense against biotic stresses was demonstrated in the presence of endophytic fungi Colletotrichum and Serendipita [147-149]. Moreover, it has been suggested that Trichoderma representatives display distinctly different transcriptional maize root recognition and active colonization, which is connected with the regulation of genes encoding phytohormones and cell wall degradation [150].

\section{Conclusions}

In this paper, we assumed that the endophythic microbiota have many important and beneficial functions, i.e., they can produce many valuable metabolites, stimulate plant growth, and support plants in overcoming different environmental stresses, based on the newest literature findings (mostly not older than 10 years). The fact that edophytes can be successfully implemented in agriculture and biotechnological processes was revealed.

A comprehensive summary of the beneficial functions of identified endophytes colonizing different parts of plants with examples of strains that can be applied in bioremediation and biotransformation processes, biosynthesis of bioactive compounds, and commercial-scale production of biofertilizers and/or biopreparations were presented. It should be emphasized that properly prepared biopreparations will be the future of agriculture, and endophytes have great potential to be used as biopreparation components. A wider use and availability of biopreparations can reduce the application of mineral/chemical fertilizers and, consequently, can contribute to an increase in biodiversity in agriculturally exploited sites.

Although many studies of endophytes have been carried out for a long time and new extensive knowledge has been provided, some problems remain unresolved and they require recognition. As suggested by all facts presented in this mini-review and in our opinion, the next studies of endophytic microbiota should focus on:

(a) development and enhancement of the efficiency of culture bioreactors in a lab-scale and industrial production, and

(b) search for novel properties of metabolites synthesized by endophytic microorganisms that may be used as effective substances that are applicable in the development of biopreparations. 
Author Contributions: Conceptualization, A.K. and A.W.; investigation, A.K., K.W. and A.W.; writing-original draft preparation, A.K. and K.W.; writing—review and editing, A.W.; visualization, K.W., A.K.; supervision, A.W.; funding acquisition, A.K.

Funding: This research was supported by the National Centre for Research and Development under the LIDER IX program (0024/1-9/2017).

Acknowledgments: The John Paul II Catholic University of Lublin are acknowledged for their financial support to the study.

Conflicts of Interest: The authors declare no conflict of interest.

\section{References}

1. Tenguria, R.K.; Khan, F.N.; Quereshi, S. Endophytes-mines of pharmacological therapeutics. World J. Sci. Technol. 2011, 1, 127-149.

2. Stępniewska, Z.; Kuźniar, A. Endophytic microorganisms-promising applications in bioremediation of greenhouse gases. Appl. Microbiol. Biotechnol. 2013, 97, 9589-9596. [CrossRef] [PubMed]

3. Pylak, M.; Oszust, K.; Frac, M. Review report on the role of bioproducts, biopreperations, biostimulants and microbial inoculants in organic production of fruit. Rev. Environ. Sci. Biotechnol. 2019. [CrossRef]

4. Hardoim, P.R.; van Overbeek, L.S.; Berg, G.; Pirttila, A.M.; Compant, S.; Campisano, A.; Doring, M.; Sessitsch, A. The hidden world within plants: Ecological and evolutionary considerations for defining functioning of microbial endophytes. Microbiol. Mol. Biol. Rev. 2015, 79, 293-320. [CrossRef]

5. Tan, R.X.; Zou, W.X. Endophytes: A rich source of functional metabolites. Nad. Prod. Rep. 2001, 18, 448-459. [CrossRef]

6. Frank, A.C.; Saldierna, G.J.P.; Shay, J.E. Transmission of bacterial endophytes. Microorganisms 2017, 5, 70. [CrossRef]

7. Toubal, S.; Bouchenak, O.; Elhaddad, D.; Yahiaoui, K.; Boumaza, S.; Arab, K. MALDI-TOF MS detection of endophytic bacteria associated with great nettle (Urtica dioica L.), grown in Algeria. Pol. J. Microbiol. 2018, 67, 67-72. [CrossRef]

8. Yaish, M.W.; Al-Lawati, A.; Jana, G.A.; Patankar, V.H.; Glick, B.R. Impact of soil salinity on the structure of the bacterial endophytic community identified from the roots of Caliph Medic (Medicago truncatula). PLoS ONE 2016, 11, e0179007. [CrossRef]

9. Le Cocq, K.; Gurr, S.J.; Hirscg, P.R.; Mauchline, T.H. Exploitation of endophytes for sustainable agricultural intensification. Mol. Plant Pathol. 2017, 18, 469-473. [CrossRef]

10. Liu, H.; Carvalhais, L.C.; Crawford, M.; Singh, E.; Dennis, P.G.; Pieterse, C.M.J.; Schenk, P.M. Inner plant values: Diversity, colonization and benefits from endophytic bacteria. Front. Microbiol. 2017, 8, 2552. [CrossRef]

11. Akinsanya, M.A.; Goh, J.K.; Lim, S.P.; Ting, A.S. Metagenomics study of endophytic bacteria in Aloe vera using next-generation technology. Genom. Data 2015, 6, 159-163. [CrossRef] [PubMed]

12. Eichmeier, A.; Pećenka, J.; Peňázová, E.; Baránek, M.; Catalá-García, S.; León, M.; Armengol, J.; Gramaje, D. High-throughput amplicon sequencing-based analysis of active fungal communities inhabiting grapevine after hot-water treatments reveals unexpectedly high fungal diversity. Fungal Ecol. 2018, 36, 26-38. [CrossRef]

13. Kunda, P.; Dhal, P.K.; Mukherjee, A. Endophytic bacterial community of rice (Oryza sativa L.) from coastal saline zone of West Bengal: 16S rRNA gene based metagenomics approach. Meta Gene 2018, 18, 79-86. [CrossRef]

14. Nguyen, H.Q.; Vu, N.T.H.; Chu, H.H.; Chu, S.K.; Hoang, H.; Tran, T.T.; Nguyen, C.; Dinh, L.T.M.; Trinh, H.T.T.; Phib, T.Q. Draft genome sequence of Streptomyces cavourensis YBQ59, an endophytic producer of antibiotics bafilomycin D, Nonactic Acid, Prelactone B, and 5,11-Epoxy-10-Cadinanol. Microbiol. Res. Ann. 2018, 7, 1-2. [CrossRef] [PubMed]

15. Battu, L.; Reddy, M.M.; Goud, B.S.; Ulaganathan, K.; Kandasamy, U. Genome inside genome: NGS based identification and assembly of endophytic Sphingopyxis granuli and Pseudomonas aeruginosa genomes from rice genomic reads. Genomics 2017, 109, 141-146. [CrossRef] [PubMed]

16. Tanjung, Z.A.; Aditama, R.; Sudania, W.M.; Utomo, C.; Liwang, T. Metagenomics workflow analysis of endophytic bacteria from oil palm fruits. J. Phys. Conf. Ser. 2017, 835, 1-6. [CrossRef] 
17. Mareque, C.; Freitas da Silva, T.; Vollú, R.E.; Beracochea, M.; Seldin, L.; Battistoni, F. The endophytic bacterial microbiota associated with sweet sorghum (Sorghum bicolor) is modulated by the application of chemical $\mathrm{N}$ fertilizer to the field. Int. J. Genom. 2018, 2018, 1-10. [CrossRef]

18. Wolińska, A. Metagenomic achievements in microbial diversity determination in croplands: A review. In Microbial Diversity in Genomic Era; Das, S., Dash, H.R., Eds.; Academic Press: Cambridge, MA, USA, 2019; Chapter 2; pp. 15-35.

19. Goodwin, S.; McPherson, J.D.; McCombie, W.R. Coming of age: Ten years of next-generation sequencing technologies. Nat. Rev. Genet. 2016, 17, 333-351. [CrossRef]

20. Dijk, W.; Jaszczyszyn, Y.; Naquin, D.; Thermes, C. The third revolution in sequencing technology. Trends Genet. 2018, 34, 666-681. [CrossRef]

21. Wolińska, A.; Kuźniar, A.; Zielenkiewicz, U.; Banach, A.; Izak, D.; Stępniewska, Z.; Błaszczyk, M. Metagenomic analysis of some potential nitrogen-fixing bacteria in arable soils at different formation process. Microb. Ecol. 2017, 73, 162-176. [CrossRef]

22. Egan, A.N.; Schlueter, J.; Spooner, D.M. Applications of next-generation sequencing in plant biology. Am. J. Bot. 2012, 99, 175-185. [CrossRef] [PubMed]

23. Maropola, M.K.A.; Ramond, J.B.; Trindade, M. Impact of metagenomic DNA extraction procedures on the identiable endophytic bacterial diversity in Sorghum bicolour (L. Moench). J. Microbiol. Met. 2015, 112, 104-117. [CrossRef] [PubMed]

24. Gonzalez-Escobedo, R.; Briones-Roblero, C.I.; Pineda-Mendoza, R.M.; Rivera-Orduña, F.N.; Zúñiga, G. Bacteriome from Pinus arizonica and P. durangensis: Diversity, comparison of assemblages, and overlapping degree with the gut bacterial community of a bark beetle that kills pines. Front. Microbiol. 2018, 9, 1-14. [CrossRef] [PubMed]

25. Fadrosh, D.W.; Ma, B.; Gajer, P.; Sengamalay, N.; Ott, S.; Brotman, R.M.; Ravel, J. An improved dual-indexing approach for multiplexed 16S rRNA gene sequencing on the Illumina MiSeq platform. Microbiome 2014, 2, 6. [CrossRef] [PubMed]

26. Grada, A.; Weinbrecht, K. Next-Generation Sequencing: Methodology and Application. J. Investig. Dermatol. 2013, 133, e11. [CrossRef] [PubMed]

27. Muzzey, D.; Evans, E.A.; Lieber, C. Understanding the basics of NGS: From mechanism to variant calling. Curr. Genet. Med. Rep. 2015, 3, 158-165. [CrossRef] [PubMed]

28. Rhoads, A.; Au, K.F. PacBio sequencing and its applications. Genom. Proteom. Bioinform. 2015, 13, $278-289$. [CrossRef]

29. Brown, S.D.; Nagaraju, S.; Utturkar, S.; De Tissera, S.; Segovia, S.; Mitchell, W.; Land, M.L.; Dassanayake, A.; Köpke, M. Comparison of singe-molecule sequencing and hybrid approaches for finishing the genome of Clostridium autoethanogenum and analysis of CRISPR systems in industrial relevant Clostridia. Biotechnol. Biofuels 2014, 7, 40. [CrossRef]

30. Tibpromma, S.; Hyde, K.D.; Bhat, J.D.; Mortimer, P.E.; Xu, J.; Promputtha, I.; Doilom, M.; Yang, J.; Tang, A.M.C.; Karunarathna, S.C. Identification of endophytic fungi from leaves of Pandanaceae based on their morphotypes and DNA sequence data from southern Thailand. MycoKeys 2018, 33, 25-67. [CrossRef]

31. Blawid, R.; Silva, J.M.F.; Nagata, T. Discovering and sequencing new plant viral genomes by next-generation sequencing: Description of a practical pipeline. Ann. Appl. Biol. 2017, 170, 301-314. [CrossRef]

32. Chaudhry, V.; Sharma, S.; Bansal, K.; Patil, P.B. Glimpse into the genomes of rice endophytic bacteria: Diversity and distribution of Firmicutes. Front. Microbiol. 2017, 7, 1-5. [CrossRef] [PubMed]

33. Annapurna, K.; Govindasamy, V.; Sharma, M.; Ghosh, A.; Chikara, S.K. Whole genome shotgun sequence of Bacillus paralicheniformis strain KMS 80, a rhizobacterial endophyte isolated from rice (Oryza sativa L.). 3 Biotech 2018, 8, 223. [CrossRef] [PubMed]

34. Ren, Z.; Tang, S.; Jiang, Y.; Jiang, M.; Zheng, S.; Liu, W.; Yang, Z.; Sang, S.; Chen, Z.; Xia, T.; et al. High-throughput sequencing analysis of endophytic bacteria diversityin fruits of white and red pitayas from three different origins. Pol. J. Microbiol. 2018, 67, 27-35. [CrossRef]

35. Dissanayake, A.J.; Purahong, W.; Wubet, T.; Hyde, K.D.; Zhang, W.; Xu, H.; Zhang, G.; Fu, C.; Liu, M.; Xing, Q.; et al. Direct comparison of culture-dependent and culture-independent molecular approaches reveal the diversity of fungal endophytic communities in stems of grapevine (Vitis vinifera). Fungal Divers. 2018, 90, 85-107. [CrossRef] 
36. Thomas, P.; Sekhar, A.C.; Shaik, S.P. High taxonomic diversity of cultivation-recalcitrant endophytic bacteria in grapevine field shoots, their in vitro introduction, and unsuspected persistence. Planta 2017, 246, 879-898. [CrossRef] [PubMed]

37. Liao, H.-L.; Bonito, G.; Rojas, J.A.; Hameed, K.; Wu, S.; Schadt, C.W.; Labbe, J.L.; Tuskan, G.; Martin, F.M.; Grigoriev, I.V.; et al. Fungal endophytes of Populus trichocarpa alter host phenotype, gene expression and rhizobiome composition. Mol. Plant Microb. Interact. 2019. [CrossRef]

38. Chen, Y.T.; Yuan, Q.; Shan, L.T.; Lin, M.A.; Cheng, D.Q.; Li, C.Y. Antitumor activity of bacterial exopolysaccharidesfrom the endophyte Bacillus amyloliquefaciens sp. isolated from Ophiopogon japonicas. Oncol. Lett. 2013, 5, 1787-1792. [CrossRef] [PubMed]

39. Asaf, S.; Khan, A.L.; Khan, M.A.; Al-Harrasi, A.; Lee, I.J. Complete genome sequencing and analysis of endophytic Sphingomonas sp. LK11 and its potential in plant growth. 3 Biotech 2018, 8, 389. [CrossRef]

40. Naylor, D.; DeGraaf, S.; Purdom, E.; Coleman-Derr, D. Drought and host selection influence bacterial community dynamics in the grass root microbiome. ISME J. 2017, 11, 2691-2704. [CrossRef]

41. König, J.; Guerreiro, M.A.; Peršoh, D.; Begerow, D.; Krauss, J. Knowing your neighbourhood—the effects of Epichloë endophytes on foliar fungal assemblages in perennial ryegrass in dependence of season and land-use intensity. Peer J. 2018, 6, e4660. [CrossRef]

42. Bullington, L.S.; Larkin, B.G. Using direct amplification and next-generation sequencing technology to explore foliar endophyte communities in experimentally inoculated western white pines. Fungal Ecol. 2015, 17, 170-178. [CrossRef]

43. Ali, S.; Charles, T.C.; Glick, B.R. Amelioration of high salinity stress damage by plant growth-promoting bacterial endophytes that contain ACC deaminase. Plant Physiol. Biochem. 2014, 80, 160-167. [CrossRef] [PubMed]

44. Pandey, R.; Chavan, P.N.; Walokar, N.M.; Sharma, N.; Tripathi, V.; Khetmalas, M.B. Pseudomonas stutzeri RP1: A versatile plant growth promoting endorhizospheric bacteria inhabiting sunflower (Helianthus annus). Res. J. Biotechnol. 2013, 8, 48-55.

45. Singh, M.; Kumar, A.; Singh, R.; Pandey, K.D. Endophytic bacteria: A new source of bioactive compounds. 3 Biotech 2017, 7, 315. [CrossRef]

46. Etesami, H.; Maheshwari, D.K. Use of plant growth promoting rhizobacteria (PGPRs) with multiple plant growth promoting traits in stress agriculture: Action mechanisms and future prospects. Ecotoxicol. Environ. Saf. 2018, 156, 225-246. [CrossRef]

47. Zúñiga, A.; de la Fuente, F.; Lionne, F.F.C.; Bônnet, J.; de Lorenzo, V.; González, B. An engineered device for indoleacetic acid production under quorum sensing signals enables Cupriavidus pinatubonensis JMP134 to stimulate plant growth. ACS Synt. Biol. 2018, 7, 1519-1527. [CrossRef]

48. Dawwam, G.E.; Elbeltagy, A.; Emara, H.M.; Abbas, I.H.; Hassan, M.M. Beneficial effect of plant growth promoting bacteriaisolated from the roots of potato plant. Ann. Agric. Sci. 2013, 58, 195-201. [CrossRef]

49. Yu, J.; Yu, Z.H.; Fan, G.Q.; Wang, G.H.; Liu, X.B. Isolation and characterization of indole acetic acid producing root endophytic bacteria and their potential for promoting crop growth. J. Agric. Sci. Tech. 2016, 18, 1381-1391.

50. Patil, N.B.; Gajbhiye, M.; Ahiwale, S.S.; Gunjal, A.B.; Kapadnis, B.P. Optimization of indole acetic acid (IAA) production by Acetobacter diazotrophicus L1 isolated from Sugarcane. Int. J. Environ. Sci. 2011, 2, 295-302.

51. UmaMaheswari, T.; Anbukkarasi, K.; Hemalatha, T.; Chendrayan, K. Studies on phytohormone producing ability of indigenous endophytic bacteria isolated from tropical legume crops. Int. J. Curr. Microbiol. Appl. Sci. 2013, 2, 127-136.

52. Franche, C.; Lindström, K.; Elmerich, C. Nitrogen-fixing bacteria associated with leguminous and non-leguminous plants. Plant Soil 2009, 321, 35-59. [CrossRef]

53. Dimkpa, C.; Weinand, T.; Asch, F. Plant-rhizobacteria interactions alleviate abiotic stress conditions. Plant Cell Environ. 2009, 32, 1682-1694. [CrossRef] [PubMed]

54. Kumar, S.R.S.; Rao, K.V.B. Biological nitrogen fixation: A review. Int. J. Adv. Life Sci. 2012, 1, 1-9.

55. Ohyama, T.; Momose, A.; Ohtake, N.; Sueyoshi, K.; Sato, T.; Nakanishi, Y.; Asis, C.A.; Ruamsungsri, S.; Ando, S. Nitrogen fixation in sugarcane. Adv. Biol. Ecol. Nitrogen Fix. 2014, 3, 49-70.

56. Aryantha, I.N.P.; Hidiyah, A.R.M. Colonization and performance of diazotroph endophytic bacteria on palm oil (Elaeis guineensis Jacq L.) leaves. In IOP Conference Series: Earth and Environmental Science; IOP Publishing Ltd.: Bristol, UK, 2018; Volume 166, Conference 1. 
57. Sharma, S.; Roy, S. Isolation and identification of a novel endophyte from a plant Amaranthus spinosus. Int. J. Curr. Microbiol. Appl. Sci. 2017, 4, 785-798.

58. Prayitno, J.; Rolfe, B. Characterization of endophytic diazotroph bacteria isolated from rice. Hay. J. Biosci. 2010, 7, 73-78. [CrossRef]

59. Saleem, M.; Arshad, M.; Hussain, S.; Bhatti, A.S. Perspective of plant growth promoting rhizobacteria (PGPR) containing ACC deaminase in stress agriculture. J. Ind. Microbiol. Biotechnol. 2007, 34, 635-648. [CrossRef]

60. Long, H.H.; Schmidt, D.D.; Baldwin, I.T. Native bacterial endophytes promote host growth in a species-specific manner; phytohormone manipulations do not result in common growth responses. PLoS ONE 2008, 3, e2702. [CrossRef]

61. Grobelak, A.; Kokot, P.; Świątek, J.; Jaskulak, M.; Rorat, A. Bacterial ACC deaminase activity in promoting plant growth on areas contaminated with heavy metals. J. Ecol. Engin. 2018, 19, 150-157. [CrossRef]

62. Zhao, L.; Xu, Y.; Chang, J.; Li, M.; Zhang, Y.; Dang, Y.; Wang, M.; Cheng, Y.; Zhang, B. Screening, resistance and growth-promoting effect of endophytic bacteria with ACC deaminase activity isolated from soybean nodules. Wei Sheng Wu Xue Bao 2016, 56, 1009-1021.

63. Ivanova, E.G.; Fedorov, D.N.; Doronina, N.V.; Trotsenko, Y.A. Production of vitamin B12 in aerobic methylotrophic bacteria. Microbiology 2006, 75, 494-496. [CrossRef]

64. Mercado, B.J.; Bakker, P.A. Interaction between plants and beneficial Pseudomonas sp., exploiting bacterial traits for crop protection. Antonie Leeuwenhok. 2007, 92, 367-389. [CrossRef] [PubMed]

65. Chandrasekeran, M.; Paramasivan, M.; Chun, S.C. Bacillus subtilis CBR05 induces vitamin B6 biosynthesis in tomato through the de novo pathway in contributing disease resistance against Xanthomonas campestris pv. Vesicatoria. Sci. Rep. 2019, 9, 6495. [CrossRef]

66. Black, L.J.; Lucas, R.M.; Sferriff, J.L.; Bjorn, L.O.; Bornman, J.F. In pursuit of vitamin D in plants. Nutrients 2017, 9, 136. [CrossRef] [PubMed]

67. De Souza Leite, T.; Cnossen-Fassoni, A.; Pereira, O.L.; Mizubuti, E.S.; de Araujo, E.F.; de Queiroz, M.V. Novel and highly diverse fungal endophytes in soybean revealed by the consortium of two different techniques. J. Microbiol. 2013, 51, 56-69. [CrossRef]

68. Flores-Felix, J.D.; Silva, R.L.; Rivera, L.P.; Marcos-Garcia, M.; Garcia-Fraile, P.; Martinez-Molina, E.; Mateos, P.F.; Velazquez, E.; Andrade, P.; Rivas, R. Plants probiotics as a tool to produce highly functional fruits: The case of Phyllobacterium and vitamin C in strawberries. PLoS ONE 2015, 10, e012228. [CrossRef]

69. Vaidehi, K.; Sekar, C. Amino acid conjugated hydroxamate type of siderophore production in Methylobacterium phyllosphaerae mb-5. Cibtech J. Microbiol. 2012, 1, 24-30.

70. Liaqat, F.; Eltem, R. Identification and characterization of endophytic bacteria isolated from in vitro cultures of peach and pear rootstocks. 3 Biotech 2016, 6, 120. [CrossRef]

71. Goudjal, Y.; Zamoum, M.; Sabaou, N.; Mathieu, F.; Zitouni, A. Potential of endophytic Streptomyces spp. for biocontrol of Fusarium root rot disease and growth promotion of tomato seedlings. Biocon. Sci. Tech. 2016, 26, 1691-1705. [CrossRef]

72. Jasim, B.; Joseph, A.A.; John, C.J.; Mathew, J.; Radhakrishnan, E.K. Isolation and characterization of plant growth promoting endophytic bacteria from the rhizome of Zingiber officinale. 3 Biotech 2014, 4, 197-204. [CrossRef]

73. Zardak, S.G.; Dehnavi, M.M.; Salehi, A.; Gholamhoseini, M. Effects of using arbuscular mycorrhixal fungi to alleviate drought stress on the physiological traits and essential oil yield of fennel. Rhizosphere 2018, 6, 31-38. [CrossRef]

74. Pusenkova, L.I.; Il'yasova, E.Y.; Lastochkina, O.V.; Maksimov, I.V.; Leonova, S.A. Changes in the species composition of the rhizosphere and phyllosphere of sugar beet under the impact of biological preparations based on endophytic bacteria and their metabolites. Eur. Soil Sci. 2016, 49, 1136-1144. [CrossRef]

75. Gveroska, B. Fungicidal and stimulating effect of biopreparation TRIANUM P on tobacco seedlings. Tutun Tab. 2017, 67, 48-55.

76. Horoszkiewicz-Janka, J.; Jajor, E. An influence of the selected bioproducts used as barley seed dressings on fungi establishment. J. Res. Appl. Agric. Eng. 2007, 52, 61-66.

77. Badawi, M.H.; EL-Henawy, H.M.; Abd-Elgaffar, N.Y. Biomanagement of Fusarium solani and Rhizoctonia solani causing root rot and damping off diseases in common bean (Phaseolus vulgaris L.) via innovative rhizobacterial formulations. J. Appl. Sci. Res. 2013, 9, 321-329.

78. Vessey, J.K. Plant growth promoting rhizobacteria as biofertilizers. Plant Soil 2003, 255, 571-586. [CrossRef] 
79. Mwajita, M.R.; Murage, H.; Tani, A.; Kahangi, E.M. Evaluation of rhizosphere, rhizoplane andphyllosphere bacteria and fungi isolated from ricein Kenya for plant growth promoters. Springer Plus 2013, 2, 1-9. [CrossRef]

80. Vurukonda, S.S.K.P.; Vardharajula, S.; Shrivastava, M.; SkZ, A. Enhancement of drought stress tolerance in crops by plant growth promoting rhizobacteria. Microbiol. Res. 2016, 184, 13-24. [CrossRef]

81. Li, H.; Wang, X.; Han, M.; Zhao, Z.; Wang, M.; Tang, Q.; Liu, C.; Kemp, B.; Gu, Y.; Shuang, J.; et al. Endophytic Bacillus subtilis ZZ120 and its potential application in control of replant diseases. Afric. J. Biotechnol. 2012, 11, 231-242.

82. Gómez, O.C.; Luiz, J.H.H. Endophytic fungi isolated from medicinal plants: Future prospects of bioactive natural products from Tabebuia/Handroanthus endophytes. Appl. Microbiol. Biotechnol. 2018, 102, 9105. [CrossRef]

83. Gai, C.S.; Dini-Andreote, F.; Andreote, F.D.; Lopes, J.R.S.; Araújo, W.L.; Miller, T.A.; Azevedo, J.L.; Lacava, P.T. Endophytic bacteria associated to sharpshooters (Hemiptera: Cicadellidae), insect vectors of Xylella fastidiosa subsp. pauca. Plant Pathol. Microbiol. 2011, 2,1-8.

84. Guerrero, A.P.M. Interrelationships Between Mutualistic Endophytic Microorganisms, the Root-knot Nematode Meloidogyne Incognita and the Sap-sucking Insect Aphis Gossypii on Tomato, Squash and Arabidopsis. Ph.D. Thesis, Universitat Bonn, Bonn, Germany, 2011; pp. 1-125.

85. Muzzamal, H.; Sarwar, R.; Sajid, I.; Hasnain, S. Isolation, identification and screening of endophytic bacteria antagonistic to biofilm formers. Pak. J. Zool. 2012, 44, 249-257.

86. Braga, R.M.; Padilla, G.; Araújo, W.L. The biotechnological potential of Epicoccum spp.: Diversity of secondary metabolites. Crit. Rev. Microbiol. 2018, 44, 759-778. [CrossRef] [PubMed]

87. Da Silva, C.F.; Vitorino, L.C.; Soares, M.A.; Souchie, E.L. Multifunctional potential of endophytic and rhizospheric microbial isolates associated with Butia purpurascens roots for promoting plant growth. Antoine Van Leeuwenhoek 2018, 111, 2157-2174. [CrossRef] [PubMed]

88. Min, Y.J.; Park, M.S.; Fong, J.J.; Quan, Y.; Jung, S.; Lim, Y.W. Diversity and saline resistance of endophytic fungi associated with Pinus thunbergii in coastal shelterbelts of Korea. J. Microbiol. Biotechnol. 2014, 24, 324-333. [CrossRef] [PubMed]

89. Rodriguez, R.J.; Henson, J.; Van Volkenburgh, E.; Hoy, M.; Wright, L.; Beckwith, F.; Kim, Y.O.; Redman, R.S. Stress tolerance in plants via habitat-adapted symbiosis. ISME J. 2008, 2, 404-416. [CrossRef] [PubMed]

90. Kernaghan, G.; Mayerhofer, M.; Griffin, A. Fungal endophytes of wild and hybrid Vitis leaves and their potential for vineyard biocontrol. Can. J. Microbiol. 2017, 63, 583-595. [CrossRef]

91. Lata, R.; Chowdhury, S.; Gond, S.K.; White, J.F. Induction of abiotic stress tolerance in plants by endophytic microbes. Lett. Appl. Microbiol. 2018, 66, 268-276. [CrossRef]

92. Park, Y.H.; Kim, Y.; Mishra, R.C.; Bae, H. Fungal endophytes inhabiting mountain-cultivated ginseng (Panax ginseng Meyer): Diversity and biocontrol activity against ginseng pathogens. Sci. Rep. 2017, 7, 16221. [CrossRef]

93. Khan, A.L.; Hamayun, M.; Ahmad, N.; Hussain, J.; Kang, S.M.; Kim, Y.H.; Adnan, M.; Tang, D.S.; Waqas, M.; Radhakrishnan, R.; et al. Salinity stress resistance offered by endophytic fungal interaction between Penicillium minioluteum LHL09 and Glycine max L. J. Microbiol. Biotechnol. 2011, 2, 893-902. [CrossRef]

94. Hemida, K.A.; Reyad, A.M.M. Improvement salt tolerance of safflower plants by endophytic bacteria. J. Hortic. Plant Res. 2019, 5, 38-56. [CrossRef]

95. Ahmad, N.M.; Hamayun, S.A.; Khan, A.L.; Lee, I.J.; Shin, D.H. Gibberellin-producing endophytic fungi isolated from Monochoria vaginalis. J. Microbiol. Biotechnol. 2010, 20, 1744-1749. [PubMed]

96. Kane, K.H. Effects of endophyte infection on drought stress tolerance of Lolium perenne accessions from the Mediterranean region. Environ. Exp. Bot. 2011, 71, 337-344. [CrossRef]

97. Hubbard, M.; Germida, J.J.; Vujanovic, V. Fungal endophytes enhance wheat heat and drought tolerance in terms of grain yield and second-generation seed viability. J. Appl. Microbiol. 2014, 116, 109-122. [CrossRef] [PubMed]

98. Vigani, G.; Rolli, E.; Marasco, R.; Dell'Orto, M.; Michoud, G.; Soussi, A.; Raddadi, N.; Borin, S.; Sorlini, C.; Zocchi, G.; et al. Root bacterial endophytes confer drought resistance and enhance expression and activity of a vacuolar $\mathrm{H}^{+}$pumping pyrophosphatase in pepper plants. Environ. Microbiol. 2018. [CrossRef]

99. Vaishnav, A.; Shukla, A.K.; Sharma, A.; Kumar, R.; Choudhary, D.K. Endophytic bacteria in plant salt stress tolerance: Current and future prospects. J. Plant Growth Reg. 2018. [CrossRef] 
100. Ngumbi, E.; Kloepper, J. Bacterial-mediated drought tolerance: Current and future prospects. Appl. Soil Ecol. 2016, 105, 109-125. [CrossRef]

101. Dastogeer, K.M.G.; Li, H.; Sivasithamparam, K.; Jones, M.G.K.; Wylie, S.J. Fungal endophytes and virus confer drought tolerance to Nicotiana benthamiana plants through modulating osmolytes, antioxidant enzymes and expression of host drought responsive genes. Environ. Exp. Bot. 2018, 149, 95-108. [CrossRef]

102. Li, K.Q.; Xu, X.Y.; Huang, X.S. Identification of differentially expressed genes related to dehydration resistance in a highly drought-tolerant pear, Pyrus betulaefolia, as through RNA-Sequencing. PLoS ONE 2016, 11, e0149352. [CrossRef]

103. Bao, A.K.; Du, B.Q.; Touil, L.; Kang, P.; Wang, Q.L.; Wang, S.M. Co-expression of tonoplast cation $/ \mathrm{H}^{+}$ antiporter and $\mathrm{H}^{+}$-pyrophosphatase from xerophyte Zygophyllum xanthoxylum improves alfaalfa plant growth under salinity, drought and field conditions. Plant Biotechnol. J. 2016, 14, 964-975. [CrossRef]

104. Raza, G.; Ali, K.; Asraf, M.Y.; Mansoor, S.; Javid, M.; Asad, S. Overexpression of an $\mathrm{H}^{+}$-PPase gene from Arabidopsis in sugarcane improves drought tolerance, plant growth, and photosynthetic responses. Turk. J. Biol. 2016, 40, 109-119. [CrossRef]

105. Gaxiola, R.A.; Regmi, K.; Paez-Valencia, J.; Pizzio, G.; Zhang, S. Plant H +-PPases: Reversible enzymes with contrasting functions dependent on membrane environment. Mol. Plant 2016, 9, 317-319. [CrossRef] [PubMed]

106. Li, H.-Y.; Wei, D.-Q.; Shen, M.; Zhou, Z.-P. Endophytes and their role in phytoremediation. Fungal Divers. 2012, 54, 11-18. [CrossRef]

107. DalCorso, G.; Fasani, E.; Manara, A.; Visioli, G.; Furini, A. Heavy metal pollutions: State of the art and innovation in phytoremediation. Int. J. Mol. Sci. 2019, 20, 3412. [CrossRef]

108. Nzila, A.; Razzak, S.A.; Zhu, J. Bioaugmentation: An emerging strategy of industrial wastewater treatment for reuse and dis charge. Int. J. Environ. Res. Public Health 2016, 13, 846. [CrossRef]

109. Adams, G.O.; Fufeyin, P.T.; Okoro, S.E.; Ehinomen, I. Bioremediation, biostimulation and biouagumentation: A review. Int. J. Environ. Biorem. Biodegr. 2015, 3, 28-39.

110. Zheng, M.; Wang, W.; Hayes, M.; Nydell, A.; Tarr, M.A.; Van Bael, S.A.; Papadopoulos, K. Degradation of Macondo 252 oil by endophytic Pseudomonas putida. J. Environ. Chem. Eng. 2018, 6, 643-648. [CrossRef]

111. Pietro-Souza, W.; de Campos Pereira, F.; Mello, I.S.; Stachack, F.F.F.; Terezo, A.J.; Nunes da Cunha, C.; White, J.F.; Li, H.; Soares, M.A. Mercury resistance and bioremediation mediated by endophytic fungi. Chemosphere 2020, 240, 124874. [CrossRef]

112. Wu, J.; Kamal, N.; Hao, H.; Liu, Z.; Qian, C.; Shao, Y.; Zhong, X.; Xu, B. Endophytic Bacillus megaterium BM18-2 mutated for cadmium accumulation and improving plant growth in hybrid Pennisetum. Biotechnol. Rep. 2019, e00374. [CrossRef]

113. Suyamud, B.; Thiravetyan, P.; Gadd, G.F.; Panyapinyopol, B.; Inthorn, D. Bisphenol A removal from a plastic industry wastewater by Dracaena sanderiana endophytic bacteria and Bacillus cereus NI. Int. J. Phyt. 2019. [CrossRef]

114. Wu, T.; Xu, J.; Liu, J.; Guo, W.-H.; Li, X.-B.; Xia, J.-B.; Xie, W.-J.; Yao, Z.-G.; Zhang, Y.-M.; Wang, R.-Q. Characterization and initial application of endophytic Bacillus safensis strain ZY16 for improving phytoremediation of oil-contaminated saline soils. Front. Microbiol. 2019, 10, 991. [CrossRef]

115. Mitter, E.K.; Kataoka, R.; Renato de Freitas, J.; Germida, J.J. Potential use of endophytic root bacteria and host plants to degrade hydrocarbons. Int. J. Phyt. 2019, 21, 928-938. [CrossRef] [PubMed]

116. Baoune, H.; Aparicio, J.D.; Pucci, G.; El Hadj-Khelil, A.O.; Polti, M.A. Bioremediation of petroleum-contaminated soils using Streptomyces sp. Hlh1. J. Soils Sed. 2019, 19, 2222-2230. [CrossRef]

117. Iqbal, A.; Arshad, M.; Karthikeyan, R.; Gentry, T.J.; Rashid, J.; Iftikhar, A.I.; Schwab, A.P. Diesel degrading bacterial endophytes with plant growth promoting potential isolated from a petroleum storage facility. 3 Biotech 2019, 9, 35. [CrossRef] [PubMed]

118. Feng, N.X.; Yu, J.; Mo, C.H.; Zhao, H.M.; Li, Y.W.; Wu, B.X.; Cai, Q.Y.; Li, H.; Zhou, D.M.; Wong, M.H. Biodegradation of di-n-butyl phthalate (DBP) by a novel endophytic Bacillus megaterium strain YJB3. Sci. Tot. Environ. 2018, 616-617, 117-127. [CrossRef]

119. Huang, Y.H.; Huang, X.J.; Chen, X.H.; Cai, Q.Y.; Chen, S.; Mo, C.H.; Lü, H.; Wong, M.H. Biodegradation of di-butyl phthalate (DBP) by a novel endophytic bacterium Bacillus subtilis and its bioaugmentation for removing DBP from vegetation slurry. J. Environ. Manag. 2018, 224, 1-9. [CrossRef] 
120. Karnwal, A. Use of bio-chemical surfactant producing endophytic bacteria isolated from rice root for heavy metal bioremediation. Pert. J. Trop. Agric. Sci. 2018, 41, 699-714.

121. Sim, C.S.F.; Chen, S.H.; Ting, A.S.Y. Endophytes: Emerging tools for the bioremediation of pollutants. In Emerging and Eco-Friendly Approaches for Waste Management; Springer: Singapore, 2018; pp. 189-217. [CrossRef]

122. Fu, Y. Biotransformation of ginsenoside Rb1 to Gyp-XVII and minor ginsenoside Rg3 by endophytic bacterium Flavobacterium sp. GE 32 isolated from Panax ginseng. Lett. Appl. Microbiol. 2018, 68, 134-141.

123. Sun, K.; Habteselassie, M.Y.; Liu, J.; Li, S.; Gao, Y. Subcellular distribution and biotransformation of phenanthrene in pakchoi after inoculation with endophytic Pseudomonas sp. as probed using HRMS coupled with isotope-labeling. Environ. Pollut. 2018, 237, 858-867. [CrossRef]

124. Tam, N.T.; Tam, N.P.; Nguyen, V.T.; Hung, N.K.; Huy, C.N.; Ngoc, P.B.; Ha, C.H.; Tien, P.Q. Isolation and screening of endophytic bacteria from Ngoc Linh ginseng (Panax vietnamensis Ha et Grushv) for biosynthesis $\beta$-glucosidase. Tap. Chi. Sinh. Hoc. 2018, 40, 153-161. [CrossRef]

125. Mohd, S.; Kushwaha, A.S.; Shukla, J.; Mandrah, K.; Shankar, J.; Armaria, N.; Sabena, P.N.; Khare, P.; Narayan, R.; Dixie, S.; et al. Fungal mediated biotransformation reduces toxicity of arsenic to soil dwelling microorganism and plant. Ecotoxicol. Environ. Saf. 2019, 176, 108-118. [CrossRef] [PubMed]

126. Marconi, F.; Umpiérrez, M.L.; Gonzalez, D.; Giordano, S.R.; Rodriguez, P. Endophytic biocatalysts with enoate reductase activity isolated from Mentha pulegium. World J. Microbiol. Biotechnol. 2018, 34, 50. [CrossRef] [PubMed]

127. Ali, A.; Mohanta, T.K.; Asaf, S.; Rehman, N.; Al-Housni, S.; Al-Harrasi, A.; Khan, A.L.; Al-Rawahi, A. Biotransformation of benzoin by Sphingomonas sp. LK11 and ameliorative effects on growth of Cucumis sativus. Arch. Microbiol. 2019, 201, 591-601. [PubMed]

128. Hu, Y.; Wang, N.; Yan, X.; Yuan, Y.; Luo, F.; Jiang, Z.; Zhou, Y. Ginsenoside Re impacts on biotransformation products of ginsenoside Rb1 by Cellulosimicrobium cellulans sp. 21 and its mechanisms. Proc. Biochem. 2019, 77, 57-62. [CrossRef]

129. Ran, X.; Zhang, G.; Li, S.; Wang, J. Characterization and antitumor activity of camptothecin from endophytic fungus Fusarium solani isolated from Camptotheca acuminate. Afr. Health Sci. 2017, 17, 566-574. [CrossRef]

130. Kasaei, A.; Mobini, D.M.; Mahjoubi, F.; Saffar, B. Isolation of Taxol-producing endophytic fungi from Iranian yew through novel molecular approach and their effects on human breast cancer cell line. Curr. Microbiol. 2017, 74, 702-709. [CrossRef]

131. Sarang, H.; Rajani, P.; Vasanthakumari, M.M.; Kumara, P.M.; Siva, R.; Ravikanth, G.; Shaanker, U. An endophytic fungus, Gibberella moniliformis from Lawsonia inermis L. produces lawsone, an orange-red pigment. Antonie Van Leeuwenhoek 2017, 110, 853-862. [CrossRef]

132. Tawfike, A.F.; Romli, M.; Clements, C.; Abbott, G.; Young, L.; Schumacher, M.; Diederich, M.; Farag, M.; Edrada-Ebel, R. Isolation of anticancer and anti-trypanosome secondary metabolites from the endophytic fungus Aspergillus flocculus via bioactivity guided isolation and MS based metabolomics. J. Chromatogr. B 2019, 1106-1107, 71-83. [CrossRef]

133. Liu, H.X.; Tan, H.B.; Li, S.N.; Chen, Y.C.; Li, H.H.; Zhang, W.M. Two new metabolites from Daldinia eschscholtzii, an endophytic fungus derived from Pogostemon cablin. J. Asian Nat. Prod. Res. 2019, 21, 150-156. [CrossRef]

134. Bernardi, D.I.; das Chagas, F.O.; Monteiro, A.F.; dos Santos, G.F.; de Souza Berlinck, R.G. Secondary metabolites of endophytic Actinomycetes: Isolation, synthesis, biosynthesis, and biological activities. In Progress in the Chemistry of Organic Natural Products; Kinghorn, A., Falk, H., Gibbons, S., Kobayashi, J., Asakawa, Y., Liu, J.K., Eds.; Springer Nature Switzerland: Basel, Switzerland, 2019; Volume 108, pp. $219-265$.

135. Wang, P.; Kong, F.; Wei, J.; Wang, Y.; Wang, W.; Hong, K.; Zhu, W. Alkaloids from the mangrove-derived actinomycete Jishengella endophytica 161111. Mar. Drug 2014, 12, 477-490. [CrossRef]

136. Gonzalez-Menendez, V.; Crespo, G.; Toro, C.; Martin, J.; de Pedro, N.; Tormo, J.R.; Genilloud, O. Extending the metabolite diversity of the endophyte Dimorphosporicola tragani. Metabolites 2019, 9, 197. [CrossRef] [PubMed]

137. Ramalingam, A.; Amutha, C. Antibacterial activity of bacteria associated with red seaweeds against pathogenic bacteria of poultry and cattle. Int. J. Adv. Life Sci. 2013, 6, 13-18. 
138. De Melo, F.M.P.; Fiore, M.F.; de Moraes, L.A.B.; Silva-Stenico, M.E.; Scramin, S.; de Araújo, T.M.; de Melo, I.S. Antifungal compound produced by the cassava endophyte Bacillus pumilus MAIIIM4A. Sci. Agricol. 2009, 66, 583-592. [CrossRef]

139. Narayan, C.P.; Seung, H.J.; Jian, X.D.; Seung, H.Y. Assemblages of endophytic bacteria in chili pepper (Capsicum annuum L.) and their antifungal activity against phytopathogens in vitro. Plant Omics J. 2013, 6, 441-448.

140. Christina, A.; Christapher, V.; Bhore, S.J. Endophytic bacteria as a source of novel antibiotics: An overview. Pharm. Rev. 2013, 7, 11-16.

141. Shenpagam, H.N.; Devi, D.K.; Sinduja, G.; Sandhya, R. Isolation of endophytic Actinomycetesfrom medicinal plants and its mutational effect in biocontrol activity. Int. J. Pharm. Sci. Res. 2012, 3, 4338-4344.

142. Gond, S.K.; Bergen, M.S.; Torres, M.S.; White, J.F. Endophytic Bacillus spp. produce antifungal lipopeptides and induce host defence gene expression in maize. Microbiol. Res. 2015, 172, 79-87. [CrossRef] [PubMed]

143. Gond, S.K.; Surendra, K.; Bergen, M.S.; Torres, M.S.; White, J.F.; Kharwar, R.N. Effect of bacterial endophyte on expression of defense genes in Indian popcorn against Fusarium moniliforme. Symbiosis 2015, 66, 133-140. [CrossRef]

144. Hu, H.; Wang, C.; Li, X.; Tang, Y.; Wang, Y.; Chen, S.; Yan, S. RNA-Seq identification of candidate defense genes targeted by endophytic Bacillus cereus-mediated induced systemic resistance against Meloidogyne incognita in tomato. Pest Manag. Sci. 2018, 74, 2793-2805. [CrossRef]

145. Dong, Z.Y.; Narsing Rao, M.P.; Wang, H.F.; Fang, B.Z.; Liu, Y.H.; Li, L.; Xiao, M.; Li, W.J. Transcriptomic analysis of two endophytes involved in enhancing salt stress ability of Arabidopsis thaliana. Sci. Tot. Environ. 2019, 10, 107-117. [CrossRef]

146. Yuan, J.; Zhang, W.; Sun, K.; Tang, M.J.; Chen, P.X.; Li, X.; Dai, C.C. Comparative transcriptomics and proteomics of Atractylodes lancea in response to endophytic fungus Gilmaniella sp. AL12 reveals regulation in plant metabolism. Front. Microbiol. 2019, 10, 1208. [CrossRef] [PubMed]

147. Mejía, L.C.; Herre, E.A.; Sparks, J.P.; Winter, K.; García, M.N.; Van Bael, S.A.; Stitt, J.; Shi, Z.; Zhang, Y.; Guiltinan, M.J.; et al. Pervasive effects of a dominant foliar endophytic fungus on host genetic and phenotypic expression in a tropical tree. Front. Microbiol. 2014, 5, 479. [PubMed]

148. Sarkar, D.; Rovenich, H.; Jeena, G.; Nizam, S.; Tissier, A.; Balcke, G.U.; Mahdi, L.K.; Bonkowski, M.; Langen, G.; Zuccar, A. The inconspicuous gatekeeper: Endophytic Serendipita vermifera acts as extended plant protection barrier in the rhizosphere. New Phytol. 2019, 224, 886-901. [CrossRef]

149. Malinich, E.; Wang, K.; Mukherjee, P.K.; Kolomiets, M.; Kenerley, C.H. Differential expression analysis of Trichoderma virens RNA reveals a dynamic transcriptome during colonization of Zea mays roots. BMC Genom. 2019, 20, 280. [CrossRef] [PubMed]

150. Dinkins, R.D.; Nagabhyrub, P.; Youngc, C.A.; Westd, C.P.; Schardlb, C.L. Transcriptome analysis and differential expression in tall fescue harboring different endophyte strains in response to water deficit. Plant Genome 2019, 12. [CrossRef]

(C) 2019 by the authors. Licensee MDPI, Basel, Switzerland. This article is an open access article distributed under the terms and conditions of the Creative Commons Attribution (CC BY) license (http://creativecommons.org/licenses/by/4.0/). 